WPS4261

\title{
CLIMATE CHANGE IMPACTS ON ANIMAL HUSBANDRY IN AFRICA: A RICARDIAN ANALYSIS ${ }^{1}$
}

\section{Sungno Niggol Seo ${ }^{2}$ and Robert Mendelsohn ${ }^{3}$}

World Bank Policy Research Working Paper 4261, June 2007

The Policy Research Working Paper Series disseminates the findings of work in progress to encourage the exchange of ideas about development issues. An objective of the series is to get the findings out quickly, even if the presentations are less than fully polished. The papers carry the names of the authors and should be cited accordingly. The findings, interpretations, and conclusions expressed in this paper are entirely those of the authors. They do not necessarily represent the view of the World Bank, its Executive Directors, or the countries they represent. Policy Research Working Papers are available online at http://econ.worldbank.org.

\footnotetext{
${ }^{1}$ An earlier version of this Working Paper was published as CEEPA Discussion Paper number 9.

${ }^{2}$ University of Aberdeen Business School, United Kingdom, e-mail: niggol.seo@abdn.ac.uk.

${ }^{3}$ School of Forestry and Environmental Studies, Yale University, 230 Prospect Street, New Haven, CT 06511, USA, e-mail: niggol.seo@yale.edu and robert.mendelsohn@yale.edu Tel: 203-432-5128.
}

This paper was funded by the GEF and the World Bank. It is part of a larger study on the effect of climate change on agriculture in Africa, managed by the World Bank and coordinated by the Centre for Environmental Economics and Policy in Africa (CEEPA), University of Pretoria, South Africa. 


\section{SUMMARY}

This paper analyzes the impact of climate change on animal husbandry in Africa. It uses the Ricardian method, a cross-sectional approach, to examine the economics of animal husbandry in Africa. The net revenue from raising animals in small and large farms across Africa is regressed on climate, soil and other control variables to test the climate sensitivity of livestock. The study is based on a survey of over 9000 farmers across 11 countries conducted by the World Bank and the Global Environment Facility (GEF) project. From this dataset, 5400 farms were found to rely on livestock.

Two empirical models were tested. A single-equation model examines net revenue per farm, regressed on climate and other control variables. The second model has two equations: the first examines the value of animals owned per farm and the second the net revenue per value of owned animal. Both equations in the second model regress the dependent variable on climate and other control variables. All the estimated equations test whether small and large farms have different climate response functions. That is, the models test whether the climate coefficients of small and large farms are similar. It turns out that small farms tend to be more labor intensive, rely on native stocks, and have few animals; large farms tend to be more commercial operations, with much larger stocks and more modern approaches.

The single-equation Ricardian model finds that the livestock net revenues of large farms in Africa fall as temperatures rise but that small farms are not temperature sensitive. The twoequation model finds that higher temperatures reduce both the size of the stock and the net revenue per value of stock for large farms. However, for small farms, higher temperatures do not affect the size of the stock and they increase the net revenues per value of stock. Large farms in Africa are vulnerable to warming but small farms are not. It is likely that large farms are vulnerable to warming because they rely on species such as beef cattle that are not well suited to high temperatures. Small farms are not vulnerable to warming because they can substitute species such as goats that can tolerate high temperatures.

The single-equation model finds that increases in precipitation would reduce livestock net revenue per farm for both small and large farms. The elasticity of net revenue per farm is particularly large for small farms. The two-equation model reveals that increased precipitation reduces both the size of the stock and the net revenue per animal owned. Although higher precipitation generally increases the productivity of grasslands, it also leads to the conversion of grasslands into forest. Further, animal diseases are likely to increase with warm wet conditions. Finally, as precipitation increases, many farmers find it advantageous to shift from livestock to crops. The positive side of these precipitation findings is that if precipitation declines, livestock net revenues will increase, especially for small farmers. Livestock thus provides an important agricultural adaptation for reductions in precipitation should they occur.

The report also explores the impact of several uniform climate change scenarios that test the importance of large changes in climate in isolation. Although these scenarios are not realistic, they provide an indication of how the model behaves. A warming of $2.5^{\circ} \mathrm{C}$ increases small farm livestock income by $26 \%(+\$ 1.4$ billion). This increase comes strictly from an expansion of the stock. If the temperature rises, the net revenues per animal fall slightly. A warming of $5^{\circ} \mathrm{C}$ 
increases small farm income by $58 \%$ ( $+\$ 3.2$ billion), again largely because of an increase in the stock. By contrast, a warming of $2.5^{\circ} \mathrm{C}$ reduces large farm livestock income by $22 \%(-\$ 13$ billion) and a warming of $5^{\circ} \mathrm{C}$ reduces it by $35 \%$ ( $\$ 20$ billion). This reduction for large farms is due to both a shrinking of the stock and a reduction in net revenue per animal owned. Increased precipitation of $14 \%$ reduces small farm income by $10 \%$ ( $-\$ 0.6$ billion) mostly due to a shrinking of the stock. The same precipitation reduction reduces large farm income by $9 \%$ ( $-\$ 5$ billion) due to a reduction in both the stock and the net revenue per animal owned.

The report also tested the impact of climate scenarios predicted by three Atmospheric Oceanic General Circulation Models (AOGCMs). With the relatively hot scenario predicted by the Canadian Climate Center (CCC) model in 2100, small farms would increase net revenues by $116 \%$ ( $+\$ 6$ billion). For the large farms, CCC leads to a $23 \%$ loss ( $\$ 14$ billion) by 2100 . The 2100 results for small farms under the Center for Climate System Research (CCSR) climate scenario is an increase in net income by $152 \%$ ( $+\$ 8$ billion). For large farms, CCSR leads to losses of a negligible amount. The Parallel Climate Model (PCM) climate scenario for 2100 leads to an increase of net income by $31 \%$ ( $\$ 2$ billion) for small farms and a decrease by $27 \%$ ( $\$ 16$ billion) for large farms. In general, scenarios with low rainfall predict higher net revenues.

The analysis finds that warming is good for small farms because they can substitute animals that are heat tolerant. Large farms, by contrast, are more dependent on species such as cattle, which are not heat tolerant. The wetter scenarios are likely to be harmful to grazing animals because greater rainfall implies a shift from grasslands to forests, an increase in harmful disease vectors, and a shift from livestock to crops.

The results indicate that livestock on large farms are vulnerable to climate change and are likely to lose net revenue unless there is substantial drying. Small farms are much less vulnerable and will probably increase net revenue from climate change. Overall, because large farms dominate the sector, African livestock net revenues are expected to fall. However, if future climates turn out to be dry, livestock net revenue will increase. At least against the risk of dryness, livestock offer a good substitute for crops. 


\section{TABLE OF CONTENTS}

$\begin{array}{ll}\text { Section } & \text { Page }\end{array}$

1 Introduction 5

2 Animal husbandry in Africa: background 6

3 Theory 7

4 Data and empirical model 19

5 Ricardian results $\quad 12$

6 Climate simulations 15

$7 \quad$ Conclusion and policy implications 19

$\begin{array}{ll}\text { References } & 21\end{array}$

Appendix A: Livestock product sales 23

$\begin{array}{ll}\text { Appendix B: Livestock and product prices } & 24\end{array}$ 


\section{Introduction}

This study analyzes the effects of climate change on livestock in Africa. Although the effects of climate change on crops are well known, much less is known about the effects of climate change on livestock (Reilly et al. 1996; McCarthy et al. 2001). Yet livestock is important. Almost 80\% of African agricultural land is grazing land. African farmers depend on livestock for income, food, animal products and insurance. A study of climate impacts on agriculture must include an analysis of livestock impacts. The most careful economic analysis of animal husbandry completed to date examined the US livestock sector (Adams et al. 1999). This study predicts that the US livestock sector would be only mildly affected by warming because most livestock live in protected environments (sheds, barns, etc.) and have supplemental feed. These results are not expected to generalize to Africa because African farmers tend not to use the protective measures found in the US. In general, the animals are exposed to the outside elements and depend largely on pasture and other natural forage for nutrition. There is consequently every reason to expect that animal husbandry on farms in Africa will be sensitive to climate.

There is substantial evidence linking climate and livestock production. For example, African farmers are known to keep cattle as an insurance policy for when droughts ruin annual crops (Swinton 1988; Fafchamps et al. 1998). Climate can affect livestock both directly and indirectly. Direct effects from air temperature, humidity, wind speed and other climate factors influence animal performance: growth, milk production, wool production and reproduction (Houghton et al. 2001). Indirect effects include climatic influences on the quantity and quality of feedstuffs such as pasture, forage, grain and the severity and distribution of livestock diseases and parasites. The effect of increased $\mathrm{CO}_{2}$ on the amount of grassland seems to be neutral or positive. A decrease in mean annual precipitation in Africa is expected to have a negative impact on the grassland. However, an increase in water use efficiency resulting from $\mathrm{CO}_{2}$ doubling is estimated to increase grass production by $20-30 \%$, which could offset this negative effect. Simulations of grassland production in Southern Africa indicate an almost exact balancing of these two effects for that region (Scholes et al. 2000). A temperature increase is also expected to have a positive effect on the amount of grassland as forests shift to grassland. Another important factor is livestock diseases. African livestock productivity has been severely affected by vector-borne livestock diseases, such as nagana (trypanosomiasis), known as sleeping sickness. Nagana is 
transmitted to people and animals by the tsetse fly. Approximately 30\% of Africa's 160 million cattle population and comparable numbers of small ruminants are at risk (ILRI 2005). This disease is known to be climate sensitive (Ford \& Katondo 1977).

This study uses a cross-sectional method, the Ricardian model, to estimate the sensitivity of African livestock to climate (Mendelsohn et al. 1994; Mendelsohn \& Dinar 1999; Mendelsohn et al. 2001). Two models are estimated. A single-equation model regresses livestock net revenue per farm on climate, soils and other control variables. A two-equation model regresses the value of livestock owned per farm and the net revenue per value of livestock owned on the same independent variables. These two models both detect whether climate affects net revenue per farm, but the second provides more detail about what is changing on the farm. The Ricardian model is estimated on data from a survey collected as part of the GEF/WB Climate Change and African Agriculture Project (Dinar et al. 2006). Over 5000 farms with livestock are analyzed from ten countries across Africa. The estimated model is used to predict the impact of a set of uniform climate change scenarios. These scenarios test the importance of Africa-wide changes in climate such as a $2.5^{\circ} \mathrm{C}$ change in temperature or a $14 \%$ change in precipitation. Finally, a set of climate predictions from Atmospheric Ocean General Circulation Models (AOGCMs) are analyzed. These three scenarios provide a realistic range of future climate outcomes. The estimated model is used to test the magnitude of the impacts on both small and large livestock farms in each scenario.

Section 2 discusses livestock husbandry in Africa to provide a background for the study; Section 3 presents a theoretical model of a profit-maximizing livestock farmer; Section 4 discusses the data, which includes an extensive survey, the relevant information on climate, soils and water, and the empirical specification; Section 5 examines the Ricardian results; and Section 6 explores the impacts of two sets of climate scenarios: the uniform climate change scenarios and the AOGCM climate scenarios. The paper concludes with some general observations and policy implications.

\section{Animal husbandry in Africa: Background}

Using the data collected from the ten-country survey, a few basic facts about Africa animal husbandry become clear. For example, Table 1 summarizes livestock ownership by two different 
types of farms: small and large. It shows the numbers and market values of each animal. Table 1 shows that large farms own over $95 \%$ of the market value of livestock in Africa. Although this fraction varies across countries, large farms dominate livestock ownership in every country. This is not because there are more large farms than small farms. Ethiopia, Ghana, Niger, Senegal, Zambia and Cameroon have many more small than large farms. Kenya, Burkina Faso, and Egypt have about an equal number of both. Only South Africa has mostly large farms. Large farms simply have many more animals per farm compared to small household farms. This is especially true in Kenya and South Africa.

Table 1 also reveals the species composition of farms in each country. The large farms in Kenya raise dairy cattle. Large farms in South Africa and Kenya also raise a large number of beef cattle. Cattle are by far the most valuable species, which is again why large farms dominate the livestock sector. South Africa also has some very large sheep farms. Niger has relatively large pig farms. Cameroon and especially Egypt have some very large chicken farms.

Because large farms have the most animals they also have the greatest livestock gross revenue. Across the sample, large farms are responsible for $96 \%$ of all livestock gross revenue in Africa. This income comes from either direct sale of animals or livestock products, including meat, milk, cheese and wool. Table 2 lists the income earned by small and large farms selling both livestock and livestock products for each country. Note that selling livestock products is more important for the small farms in Egypt, Ethiopia, Senegal and Kenya, whereas direct sale of livestock is more important for large farms except those in Ethiopia.

\section{Theory}

Farmers choose crop and livestock production. Ideally, we would like to examine a sophisticated model where farmers jointly maximize the combined profits from both crops and livestock. The focus of this paper is more limited. We start by modeling only livestock net revenues. We feel it is important to begin with a simple model of livestock before tackling the complex interactions between livestock and crops. Because crops and livestock are likely to react to climate differently, it is important to understand how livestock behaves independently of how crops behave. However, without a joint model it is not possible to fully understand the interaction between crops and livestock. 
We assume that the farmer maximizes net income by choosing which livestock to purchase and which inputs to apply:

$\operatorname{Max} \pi=P_{q_{j}} Q_{j}\left(L_{G}, F, L, K, C, W, S\right)-P_{F} F-P_{L} L-P_{K} K$

where $\pi$ is net income, $P_{q_{j}}$ is the market price of animal $j, Q_{j}$ is a production function for animal $\mathrm{j}, \mathrm{L}_{\mathrm{G}}$ is grazing land, $\mathrm{F}$ is feed, $\mathrm{L}$ is a vector of labor (hired and household), $\mathrm{K}$ is a vector of capital such as barns and milking equipment, $\mathrm{C}$ is a vector of climate variables, $\mathrm{W}$ is available water, $\mathrm{S}$ is a vector of soil characteristics of grazing land, $\mathrm{P}_{\mathrm{F}}$ is a vector of prices for each type of feed, $\mathrm{P}_{\mathrm{L}}$ is a vector of prices for each type of labor, and $\mathrm{P}_{\mathrm{K}}$ is the rental price of capital.

The farmer chooses the species $\mathrm{j}$ and the number of the animals that maximizes profit. The resulting net income will be a function of just the exogenous variables:

$\pi^{*}=f\left(P_{q}, C, W, S, P_{X}, P_{L}, P_{K}\right)$

The locus of profit maximizing solutions to Equation (1) is the Ricardian function. It explains how profits change across all the exogenous variables facing a farmer. The change in welfare, $\Delta \mathrm{U}$, resulting from a climate change from $\mathrm{C}_{0}$ to $\mathrm{C}_{1}$ can be measured using this Ricardian function as follows.

$\Delta U=\pi^{*}\left(C_{1}\right)-\pi^{*}\left(C_{0}\right)$

If the change increases net income, it will be beneficial and if it decreases net income it will be harmful. 
This model treats the farmer as though he is an income maximizing entity. Although this paradigm clearly fits large farms that act as firms, there are two issues that must be addressed for the model to fit smaller household farms. First, households use their own labor and there is no observed wage for household labor. Although one might at first assume household labor and hired labor can easily substitute for each other, empirical evidence suggests that the implicit wage rate for household labor is less than the wage for hired workers. It is not obvious what wage rate to assign to household labor. Second, households often consume a large fraction of their output. In this study, we assume that own consumption should be valued at the prevailing market prices. When households consume only a fraction of their output, this is not a strong assumption. However, when households consume all of their output, one cannot be certain that they actually valued the output at market price. For example, a remote household far from markets may place a higher price on the output than what they would get at the market.

The model is precise in the vicinity of the sample data, for example, valuing marginal changes. However, if climate changes a great deal and this leads to a dramatic change in the livestock sector, prices will be likely to change (Cline 1996). The Ricardian model will overstate welfare changes if there are large price changes.

\section{Data and empirical model}

This study is based on a survey of farmers in ten countries across Africa: Burkina Faso, Cameroon, Egypt, Ethiopia, Ghana, Kenya, Niger, Senegal, South Africa, and Zambia (Dinar et al. 2006). Data from Zimbabwe, the eleventh country in the survey, had to be dropped because of erratic responses from farmers due to tumultuous conditions in that country in the year of the survey. We define a region called 'West Africa' that includes Burkina Faso, Cameroon, Ghana, Niger and Senegal.

Districts were selected to obtain a wide range of climates within each country. Districts that could not support any agriculture (such as deserts) were not surveyed. In each country, 15-30 districts were selected. Within each district, 20-30 households were interviewed in clusters. Cluster sampling was done to control the cost of the survey.

The survey records information on the number of livestock, transactions, livestock products and related costs. The eight major livestock sold are cattle for meat, cattle for milk, breeding bulls, 
goats, sheep, pigs, oxen, and chickens. Some farmers owned additional animals such as camels, duck, guinea fowl, horses, bees and doves. The major livestock products sold were milk, beef, goat products, sheep products, eggs, wool and leather (see Appendix A). Other more minor livestock products include butter, cheese, honey, skins and manure.

Along with a large array of breeds, ${ }^{4}$ the fragile market structure in Africa makes it difficult to obtain accurate prices of animals. In our study, we used the median prices for each animal in each district in order to make our prices as robust as possible. When median district prices were not available, we used provincial median prices. If there were no provincial median prices, we used the national median price. Generally the prices for animals in Egypt and South Africa were the highest (see Appendix B). By contrast, Cameroon, Egypt, and Ethiopia had the highest prices for animal products.

Part of the problem with prices in the survey was measuring consistent units. For example, some households reported 'number of eggs sold' while others reported 'dozens of eggs sold'. Some households reported ' $\mathrm{kg}$ of beef per year' while others reported ' $\mathrm{kg}$ of beef per week'. By cleaning the data carefully, with the help of each country team, we were able to correct many observations but had to drop several cases that were unresolved.

The temperature data came from satellites which measure temperatures twice daily via a Special Sensor Microwave Imager mounted on US Defense Department satellites (Basist et al. 1998). The precipitation data was interpolated from weather stations throughout Africa by the National Oceanic and Atmospheric Administration (World Bank 2003). In both cases we used long-term measures of climate, not weather. For the satellite data we used the average temperature from 1988 through 2004. For the weather station data we used the average precipitation for 19601990 (Mendelsohn et al. 2006).

Soil data were obtained from the FAO digital soil map of the world CD ROM and extrapolated to the district level using a GIS (Geographical Information System). The dataset reports 116 dominant soil types, which we explore in the analysis.

4 See Breeds of livestock, Department of Animal Science, Oklahoma State University (www.ansi.okstate.edu/breeds/). 
We estimate two models in this report. The first model regresses net revenue per farm on climate and other control variables:

$$
\begin{aligned}
\pi_{i}=b_{0} & +b_{1} \cdot T \cdot S+b_{2} \cdot T^{2} \cdot S+b_{3} \cdot P \cdot S+b_{4} \cdot P^{2} \cdot S \\
& +b_{5} \cdot B+b_{6} \cdot T \cdot B+b_{7} \cdot T^{2} \cdot B+b_{8} \cdot P \cdot B+b_{9} \cdot P^{2} \cdot B \\
& +\sum_{j} b_{j} \cdot Z_{j}+e_{i}
\end{aligned}
$$

The dependent variable is net livestock income per household, $\mathrm{T}$ and $\mathrm{P}$ represent temperature and precipitation variables, $\mathrm{S}$ is a dummy for small farms, $\mathrm{B}$ is a dummy for large farms, $\mathrm{Z}$ represents a set of relevant socio-economic variables, and the $b_{i}$ 's are coefficients. The climate variables are introduced in a quadratic form because of earlier evidence that the relationships are nonlinear (for example Mendelsohn et al. 1994). Although seasonal climate variables were tested they were found to be insignificant. The livestock model consequently focuses on annual temperature and precipitation. By multiplying the climate variables by small and large farm dummies, we effectively estimate a separate climate response function for each farm size.

The change in income per farm caused by a marginal change in temperature evaluated at a particular annual temperature $\mathrm{T}$ for small and large farms is:

$$
\begin{aligned}
& \frac{\partial \pi_{i}}{\partial T}=b_{1}+2 \cdot b_{2} \cdot T \text { if } \mathrm{S}=1 \\
& \frac{\partial \pi_{i}}{\partial T}=b_{5}+2 \cdot b_{6} \cdot T \text { if } \mathrm{B}=1
\end{aligned}
$$

A parallel result applies for precipitation. 
We also estimate a two-equation model where we first regress the value of animals owned per farm on climate and other variables and then regress net revenue per owned animal on climate and other variables:

$$
\begin{aligned}
V_{i}=\phi_{0} & +\phi_{1} \cdot T \cdot S+\phi_{2} \cdot T^{2} \cdot S+\phi_{3} \cdot P \cdot S+\phi_{4} \cdot P^{2} \cdot S \\
& +\phi_{5} \cdot B+\phi_{6} \cdot T \cdot B+\phi_{7} \cdot T^{2} \cdot B+\phi_{8} \cdot P \cdot B+\phi_{9} \cdot P^{2} \cdot B \\
& +\sum_{j} \phi_{j} \cdot Z_{j}+e_{i} \\
\pi_{i} / V_{i}= & \gamma_{0}+\gamma_{1} \cdot T \cdot S+\gamma_{2} \cdot T^{2} \cdot S+\gamma_{3} \cdot P \cdot S+\gamma_{4} \cdot P^{2} \cdot S \\
& +\gamma_{5} \cdot B+\gamma_{6} \cdot T \cdot B+\gamma_{7} \cdot T^{2} \cdot B+\gamma_{8} \cdot P \cdot B+\gamma_{9} \cdot P^{2} \cdot B \\
& +\sum_{j} \gamma_{j} \cdot Z_{j}+e_{i}
\end{aligned}
$$

This second model decomposes the climate effect on farmers into what happens to stock versus net revenue per animal.

\section{Ricardian results}

Small farmers in Africa use livestock for animal power, own consumption and occasional sale. Large commercial farms, especially in Egypt, Kenya and South Africa, raise and process a large number of animals strictly for market sale. Because these small and large farms act quite differently, we modeled them separately.

In order to categorize farms by size, we multiplied the price of each animal by the number of animals of that species the farmer owned and summed across all the species. The resulting market value of animals provides a measure of the size of the farm. Note that we counted the number of animals owned, not the number sold. We defined a farm with less than $\$ 630$ worth of animals as a small farm and a farm with more than US\$630 worth as a large farm. On small farms in Africa the livestock is worth US\$230 on average and on large farms it is worth US\$7800 on average.

The traditional Ricardian approach as it was applied to crops analyzed land value or net revenue per hectare. But it is very difficult, at least in Africa, to measure the amount of land that farmers use for animals, since they tend to rely on open or public land. So we could not divide net 
revenue by land as is done in Ricardian crop models. The dependent variable in our first model is therefore livestock net revenue per farm. Similarly, in the second model, the value of livestock owned is per farm not per hectare. It is also important to note that the survey collected limited information about the costs of raising livestock. The definition of net revenue includes the cost of feed, hired labor, transportation, packaging, storage, veterinary care and extension. We have poor measures of pasture and household labor.

Table 3 reports the Ricardian regression of net revenue per farm. The net revenue is sensitive to whether a farm is a dairy farm. The regression shows dairy farming generates significantly lower income. It is possible that low-income households use the milk from dairy farming for own consumption and that this output was underreported on our survey. Other control variables tried in the model include the national percentage of the population that is Muslim, the percentage of pastureland and the population density. The more pastureland a country has, the higher the livestock net revenue per farm. This variable measures the scarcity of land for grazing. Countries with higher percentages of Muslim populations have lower livestock net revenue per farm. It is not clear why this statistical result is occurring. Higher population densities translate into higher net revenue because of higher net prices for output (lower transportation costs to market). Household size is significant and negative. Large households tend to have lower livestock net revenues per farm. By contrast, households with electricity have higher net revenues. Electricity may be a dummy variable for higher technology or it may signify the farm is nearer major markets. The adjusted R-sq of the regression is around 0.09 .

Soil variables were also tested but were dropped because they were not significant. Dominant soils of 116 types and 26 grouped soils were tested. Household characteristics such as the age, gender and education of the head of the farm, whether the respondent was the head of the farm, and whether the head of the farm works off the farm were also tested but found to be insignificant. Regional dummy variables for Egypt, West Africa and East Africa were also tried but found to be insignificant. Water flow was also insignificant. Elevation does not seem to play a significant role either.

The climate coefficients reveal that livestock net revenues are generally sensitive to climate variables. The climate effects vary for small and large farms. The regression shows that small 
farms are not sensitive to temperature while large farms are highly sensitive to it. Both types of farm are sensitive to rainfall changes.

The regression results for the two-equation model are presented in Table 4. The coefficients in column 2 of Table 4 describe how the independent variables affect the value of livestock owned. By definition, large farms have more livestock, $\$ 30,000$ more on average, than small farms. Larger households have less livestock, perhaps indicating that they are more likely to be small farmers. Having electricity increases livestock owned either because of more technology or better access to markets. Dairy farming decreases the value of livestock owned. Farms in places with more population density have more livestock but the effect diminishes as populations become too dense. Countries with higher Muslim populations have less livestock per farm. Farms in areas with more pasture have more livestock. Temperature has no discernible effect on the number of livestock on small or large farms. Precipitation, however, has an appreciable effect. Higher levels of precipitation reduce the stock of animals in both small and large farms.

The regression coefficients in column 4 explain how the independent variables affect the net revenue per value of livestock. To make the coefficients easier to read, we present the results in terms of US\$/year per thousand dollars of livestock value. It is interesting to contrast the results in column 2 and 4. For example, in column 4 the dummy for large farms is insignificant, which implies that there is no difference in the net revenue per animal for small and large farms. Household size does not influence net revenue per animal. Dairy farming has higher net revenue per animal. Farms in areas with more pasture get less net revenue per animal. This last effect may reflect the fact that farm areas with higher pasture have generally lower agricultural productivity. These column 4 coefficients are all different from the coefficients in column 2 . However, some of the coefficients in the two columns have the same sign and most likely the same explanation. Electricity increases the net revenue per animal. Higher population density increases net revenue per animal at a decreasing rate. Farms in countries with higher Muslim populations get less net revenue per animal.

In order to interpret the climate coefficients in Table 3 and 4, we computed the marginal climate impacts at the mean temperature and precipitation levels in Africa. These results are displayed in Table 5. For small farms, a marginal increase in temperature increases income by $\$ 100$ per 
degree, although this effect is not significant. For large farms, warmer temperatures reduce income by $\$ 400$ per degree and this effect is significant. The temperature elasticity of small farms is about +25 whereas the temperature elasticity of large farms is -2.7 . Because large farms have access to more capital and technology, one might expect that they would be less vulnerable to warming. However, the most profitable species for large farms are cattle, which do not do well in high temperatures. By contrast, small farmers find it relatively easy to shift to goats and sheep, which appear to tolerate high temperatures reasonably well.

A marginal increase in precipitation reduces net revenue per farm for both small and large farms. Small farms decline about US\$26 per mm of monthly precipitation and large farms about US\$59 per $\mathrm{mm}$ and both effects are significant. The precipitation elasticity is about -16 for small farms and -1 for large farms. Increased precipitation is associated with lower net revenue because farmers shift from livestock to crops, natural ecosystems shift from grasslands to forests, and the prevalence of animal diseases such as trypanosomiasis increases (ILRI 2005). An alternative perspective on these same marginal results is that livestock net revenue rises as precipitation falls. Crops shift to livestock, forests to grasslands, and diseases become less prevalent. From an adaptation perspective, livestock becomes a good alternative to crops if precipitation falls. As long as there is enough precipitation to support grassland, livestock incomes rise with less rainfall.

Figure 1 interprets the temperature coefficients of the climate regression in Table 3 across a range of temperature values. The income of small farms is stable over a range of temperatures, while that of large farms declines sharply as temperatures rise. Figure 2 interprets the precipitation coefficients of the Table 3 regression. The figure shows that additional rainfall reduces livestock income especially for large farms. Figure 3 shows that higher temperatures increase the stock of livestock owned for small farms but decrease the stock owned by large farms. Figure 4 shows that both small and large farms are sensitive to higher precipitation. The effect for large farms is basically linear, whereas the effect for small farms diminishes with precipitation so that the stocks of animals on the two types of farm approach each other at high levels of precipitation. Figure 5 shows that the net revenue per animal declines for both small and large farms as temperatures rise. Figure 6 show a similar response of net revenue per animal to higher precipitation, although the effect is steeper for large farms. 


\section{Climate simulations}

\section{Uniform climate change scenarios}

In order to illustrate what the regressions imply for African animal husbandry, we examined some simple uniform climate scenarios where only one climate factor changes at a time across the continent. The purpose of these simulations is to understand how non-marginal changes in each climate component affect the results. We test increases in temperature of $2.5^{\circ} \mathrm{C}$ and $5^{\circ} \mathrm{C}$, and changes in precipitation of $-7 \%,+7 \%$ and $+14 \%$. The temperature changes are added to existing temperatures in each district. The precipitation changes are multiplied by the rainfall in each district. Assuming that climate changes will be uniform across the entire continent of Africa is not realistic, but the experiments provide important insights into how the model responds to climate changes.

Table 6 compares the baseline income with the predicted impact in each of five uniform climate change scenarios. For the small farms, warming of $2.5^{\circ} \mathrm{C}$ increases livestock net revenues by $25 \%$ and warming of $5^{\circ} \mathrm{C}$ by $58 \%$. For the large farms, warming of $2.5^{\circ} \mathrm{C}$ reduces livestock net revenues by $22 \%$ and warming of $5^{\circ} \mathrm{C}$ by $35 \%$. These outcomes are consistent with the marginal analyses reported in Table 5. A 14\% increase in precipitation is expected to reduce livestock net revenues by about $10 \%$ for both small and large farms.

Table 6 also provides insights into whether these changes are due to changes in the stock of livestock owned or changes in the net revenue per animal. The increases in net revenue with warmer temperatures for small farms are due largely to changes in the number of livestock owned. Net revenues per animal actually fall slightly. The reductions in net revenue with higher temperatures for large farms, by contrast, are due to a combination of fewer animals per farm and reductions in net revenue per animal. The precipitation effects for all farms are due more to changes in the number of animals than to changes in the net revenue per animal.

\section{AOGCM climate scenarios}

We also examined the climate change scenarios predicted by AOGCMs. We relied on a broad set of scenarios that predict a wide range of outcomes, consistent with the expectations in the most recent IPCC report (Houghton et al. 2001). Specifically, we used the A1 scenarios from the 
following models: CCC (Boer et al. 2000), CCSR (Emori et al. 1999) and PCM (Washington et al. 2000). We examined country level climate change scenarios in 2100. For each climate scenario, we added the climate model's predicted change in temperature to the baseline temperature in each district. We then multiplied the climate model's predicted percentage increase in precipitation by the baseline precipitation in each district or province. This gave us a new climate for every district in Africa.

Table 7 summarizes the climate scenarios for the three models. The African mean temperature and rainfall predicted for the years 2020, 2060, and 2100 are presented. The models provide a range of predictions: by $2100 \mathrm{PCM}$ predicts a $2^{\circ} \mathrm{C}$ increase in temperature, CCSR a $4^{\circ} \mathrm{C}$ increase and $\mathrm{CCC}$ a $6^{\circ} \mathrm{C}$ increase. The temperature projections of all the models steadily increase over time. The models also provide a range of rainfall predictions: by 2100 PCM predicts a $10 \%$ increase in rainfall, $\mathrm{CCC}$ a $10 \%$ decrease and CCSR a $30 \%$ decrease. The rainfall predictions of the models do not steadily increase but rather have a varied pattern over time. CCC predicts a declining trend in rainfall; CCSR an initial decrease, then increase, and then decrease; PCM an initial increase, then decrease, and then increase again. Further, even though the mean rainfall for Africa might increase/decrease, some countries will nonetheless experience a decrease/increase in rainfall.

We then computed the net revenues per farm that the current climate and each new climate are predicted to support over all countries in Africa. Subtracting the result, we calculated the change in net revenue per farm in each location. A similar calculation was made for the value of animals per farm and the net revenue per animal.

Table 8 presents the changes in net revenue per farm predicted from the climate scenarios of the three AOGCM models for the years 2020, 2060 and 2100. These three scenarios reflect a realistic range of climate outcomes. The CCC scenario predicts increasing revenues for small farms over the next century. The results suggest small farm incomes will increase by $24 \%$ by $2020,53 \%$ by 2060 and $116 \%$ by 2100 . Large farms lose increasing amounts in the CCC scenario because of warming. The PCM scenario predicts an initial loss for small farms in 2020 that eventually turns into a gain by 2100 . Large farms lose a slightly increasing amount over time in all the PCM scenarios. The CCSR predicts the largest gains of all three models for small farms 
by 2020 and again by 2100 owing to large predicted reductions in rainfall. Large farms are predicted to lose $10 \%$ by 2020 and $24 \%$ by 2060 , but nothing by 2100 . The dramatic drying in the 2100 CCSR scenario balances the warming in this scenario.

Table 9 presents the changes in the value of animals owned per farm for each AOGCM climate scenario. Small farmers increase the number of their livestock in all scenarios except the 2020 PCM scenario, which shows a small decline. This increase in livestock is what is behind the expansion of net revenues per farm for small farms. The warmer drier scenarios encourage farmers to shift resources into livestock management. By contrast, these same climate changes cause large farmers to reduce the number of their livestock. Large farmers steadily decrease livestock holdings the warmer it gets. The one exception is the 2100 CCSR scenario where the effects of dryness balance the effects of warming, leading to just a small reduction in stock.

Table 10 presents the changes in net revenue per animal owned in each AOGCM climate scenario. All the scenarios except the 2100 CCSR scenario lead to a reduction in the net revenue per animal owned. The effects in the PCM and CCC scenarios are almost identical in 2020 and 2060. Both small and large farmers see a small reduction in net revenue per animal that increases in magnitude over time. The CCC scenario has a noticeably harsher effect by 2100 , however, as temperatures increase dramatically. The CCSR scenario is much more variable over time as precipitation decreases, increases, and then rapidly decreases. At first, this leads to almost no change in net revenues for s small farmers and a 7\% decline for large farmers. With the increase in precipitation in 2060, net revenue declines rapidly for small farmers and large farmers alike. With the subsequent dryness in 2100 , however, net revenue dramatically increases for both small and large farmers.

Table 11 presents the aggregate results for Africa. Using rural population estimates, the results from the sample of small and large farms are extrapolated to all of Africa. The results suggest that climate change will lead to billions of dollars worth of impacts in the livestock sector. In general, small farmers will gain net revenue whereas large farmers will lose it. Because large farmers dominate the sector, livestock will lose billions of dollars in net revenue in all but the 2100 CCSR scenario. The results for 2100 range from a gain of $\$ 8$ billion to a loss of $\$ 8$ to $\$ 15$ billion per year. Interestingly, the unusually dry CCSR scenario in 2100 leads to the only case of 
gains. The livestock sector provides some balance to the crop sector which depends on more rain. If there is a dry period which is hard on crops, it will lead to more income for livestock. Livestock can therefore offer farmers some protection against swings in precipitation.

Figures 7 through 12 map the percentage change of livestock income caused by different climate scenarios in 2100. Figures 7 through 9 map the impacts to small farms for each of the three climate scenarios. Figures 10 through 12 map the impacts for large farms.

For the small farms, CCC and CCSR predict an increase in livestock net revenue across Africa in 2100. CCC predicts especially large benefits in the Sahel, Central Africa and East Africa. CCSR predicts similar increases in the Sahel, Central Africa and East Africa, but also in West Africa. By contrast to the other climate models, PCM predicts almost no change in livestock net revenue across Africa in 2100.

Figure 10 demonstrates that the CCC climate scenario leads to reductions in livestock net revenue across Africa in 2100 for large farms. The reductions are especially large in the Sahel, Central Africa and East Africa. The PCM climate scenario (Figure 11) leads to very similar results to those of the CCC, with slightly more severe damages in West Africa. In the CCSR scenario (Figure 12), there is an overall increase of livestock net income for large farms in West, Central and East Africa but a decrease in South Africa and North Africa.

\section{Conclusion and policy implications}

This paper examines the climate sensitivity of livestock management in Africa. The study was based on a wide-scale survey of African farmers that measures livestock net revenues. The data were combined with climate and other variables. Net revenues per farm were then regressed on climate and other variables to test whether net revenue is sensitive to climate. The study found that livestock net revenues in Africa are highly sensitive to climate. The climate sensitivity, however, varies according to farm size. Large farms are hurt by higher temperature but small farms are not. Small farms can apparently switch from temperate animals to heat tolerant animals and will switch from crops to livestock. The result is that livestock income rises for small farms 
as temperatures rise. Large farms are more dependent on beef cattle, which are intolerant of high temperatures.

The impacts of climate change also depend on how dry the scenario is. Although rainfall generally increases crop and pasture productivity, this study shows that rainfall reduces livestock net income. There are three plausible explanations. First, farmers shift to crops as rainfall increases. Second, grassland shifts to forests as rain increases. This reduces the quality of natural grazing for most animals. Third, increases in precipitation increase the incidence of certain animal diseases.

Evaluating the predictions of climate models, we find that warming generally leads to increased revenue for small farmers and reduced revenue for large farmers. These effects may be evident as early as 2020 and generally increase over time. For small farmers, livestock will provide some protection from the effects of warming as crops become less desirable. Livestock will also do well if rainfall decreases. From a portfolio perspective, this is excellent news for small African farmers as it means that over the next century they will still have options to farm. Large livestock farms will have more trouble as temperatures rise. However, the damages foreseen are a small fraction of income so that they too are likely to be able to survive the next century, though with slightly lower incomes.

The results in this study contrast sharply with the analysis of the climate sensitivity of livestock in the US (Adams et al 1999). The US study found that American livestock were not climate sensitive. We believe this difference is due to the capital intensity of American livestock management where many animals are in protected feedlots. By contrast, African animals tend to be outdoors and depend largely on natural grazing. This direct exposure to the elements and reliance on natural ecosystems for sustenance makes African livestock far more climate sensitive.

There are several caveats readers should bear in mind. First, it was difficult to measure the land that was being used for livestock in Africa because many small farmers rely on communal lands. Second, the survey collected only limited data on the cost of raising livestock. The study did not have a complete account of all the costs of raising livestock. Third, households sometimes used their own inputs (grain, labor) and consumed their own output. Although we tried to adjust for 
own consumption using market prices, there may be some remaining errors. Fourth, prices were difficult to collect since some farmers do not sell their products, some sell at the farm gate, some sell in local markets, and some process their products before sale. We relied on median prices in each district to control for this but this adjustment may have been imperfect. Finally, in the forecasts, we have assumed that the only thing that changes over time is climate. In practice, many things will change over the next century, including population, prices, technology and institutional conditions. Future livestock owners may take advantage of new technologies that are not commonly used today in most of Africa, such as shades and sprinklers (Hahn \& Mader 1997). Genetics and breeding may also offer some new potential adaptations (Johnson 1965). Future papers should explore these many issues and develop ever more precise predictions of what may happen to livestock in Africa. 


\section{REFERENCES}

Adams RM et al., 1999. The economic effect of climate change on US agriculture. In Mendelsohn R \& Neumann J (eds), The Economic Impact of Climate Change on the Economy of the United States. Cambridge: Cambridge University Press.

Basist A, Peterson N, Peterson T \& Williams C, 1998. Using the Special Sensor Microwave Imager to monitor land surface temperature, wetness, and snow cover. Journal of Applied Meteorology 37: 888-911.

Boer G, Flato G \& Ramsden D, 2000. A transient climate change simulation with greenhouse gas and aerosol forcing: Projected climate for the 21st century. Climate Dynamics 16: 427450 .

Cline WR, 1996. The impact of global warming on agriculture: Comment. American Economic Review 86: 1309-1312.

Dinar A, Hassan R, Kurukulasuriya P, Benhin J \& Mendelsohn R, 2006. The policy nexus between agriculture and climate change in Africa. A synthesis of the investigation under the GEF / WB Project, Regional Climate, Water and Agriculture: Impacts on and Adaptation of Agro-ecological Systems in Africa. CEEPA Discussion Paper No 39, Centre for Environmental Economics and Policy in Africa, University of Pretoria.

Emori S, Nozawa T, Abe-Ouchi A, Namaguti A \& Kimoto M, 1999. Coupled ocean-atmosphere model experiments of future climate change with an explicit representation of sulfate aerosol scattering. Journal of the Meteorological Society of Japan 77: 1299-1307.

Fafchamps M, Udry C \& Czukas K, 1998. Drought and saving in West Africa: Are livestock a buffer stock? Journal of Development Economics 55: 273-305.

Ford J \& Katondo K, 1977. The Distribution of Tsetse flies in Africa. Organization of African Unity, Nairobi, Kenya.

Hahn GL \& Mader TL, 1997. Heat waves in relation to thermoregulation, feeding behavior, and mortality of feedlot cattle. Proceedings of the 5th International Livestock Environment Symposium, Minneapolis, MN, USA, pp. 563-571.

Houghton JT et al. (eds), 2001. Climate Change 2001: The Scientific Basis. Contribution of Working Group I to the third assessment report of the Intergovernmental Panel on Climate Change. Cambridge: Cambridge University Press.

ILRI (International Livestock Research Institute), 2005. http://www.ilri.org

Johnson HD, 1965. Response of animals to heat. Meteorological Monographs 6: 109-122.

McCarthy J, Canziani, OF, Leary, NA, Dokken DJ \& White C (eds), 2001. Climate Change 2001: Impacts, Adaptation, and Vulnerability. Contribution of Working Group II to the 
third assessment report of the Intergovernmental Panel on Climate Change. Cambridge: Cambridge University Press.

Mendelsohn R \& Dinar A, 1999. Climate change, agriculture, and developing countries: Does adaptation matter? The World Bank Research Observer 14: 277-293.

Mendelsohn R, Nordhaus W \& Shaw D, 1994. The impact of global warming on agriculture: A Ricardian analysis. American Economic Review 84: 753-771.

Mendelsohn R, Sanghi A \& Dinar A, 2001. The effect of development on the climate sensitivity of agriculture. Environment and Development Economics 6: 85-101.

Mendelsohn RA, Basist A, Kogan F \& Kurukulasuriya P, 2006 (forthcoming). Measuring climate change impacts with satellite versus weather station data. Climatic Change.

Reilly J et al., 1996. Agriculture in a changing climate: Impacts and adaptations. In Watson R, Zinyowera M, Moss R \& Dokken D (eds), 1996. Climate Change 1995: Impacts, Adaptations, and Mitigation of Climate Change: Scientific-Technical Analyses, Cambridge: Cambridge University Press for the Intergovernmental Panel on Climate Change (IPCC).

Scholes RJ, Midgeley G \& Wand S, 2000. The impacts of climate change on South African rangelands. In Department of Environmental Affairs \& Tourism (DEAT) South African Country Studies on Climate Change. DEAT, Pretoria, South Africa.

Swinton S, 1988. Drought survival tactics of subsistence farmers in Niger. Human Ecology 16: 123-144.

Washington W et al., 2000. Parallel Climate Model (PCM): Control and transient scenarios. Climate Dynamics 16: 755-774.

World Bank, 2003. Africa rainfall and temperature evaluation system (ARTES). World Bank, Washington DC. 


\section{APPENDICES}

Appendix A: Livestock product sales

\begin{tabular}{|c|c|c|c|c|c|c|c|c|}
\hline & $\begin{array}{l}\text { No. of } \\
\text { farms }\end{array}$ & $\begin{array}{l}\text { Milk } \\
\text { (kg) }\end{array}$ & $\begin{array}{l}\text { Beef } \\
\text { (kg) }\end{array}$ & $\begin{array}{l}\text { Sheep } \\
\text { (kg) }\end{array}$ & $\begin{array}{l}\text { Goats } \\
\text { (kg) }\end{array}$ & Eggs & Wool & Leather \\
\hline \multicolumn{9}{|c|}{ Small household farms } \\
\hline Burkina Faso & 419 & & & 0.20 & 0.47 & 15.10 & & \\
\hline Egypt & 193 & 358.17 & & & & 469.90 & 0.09 & \\
\hline Ethiopia & 338 & 28.35 & & 0.18 & & 47.81 & & 0.05 \\
\hline Ghana & 344 & & & 0.09 & 0.05 & 2.80 & & \\
\hline Niger & 322 & 1.09 & & & & 2.53 & & 0.04 \\
\hline Senegal & 492 & & & 0.09 & & 0.17 & & \\
\hline South Africa & 47 & & & & & 349.36 & & \\
\hline Zambia & 543 & & & & 0.04 & 4.83 & & \\
\hline Cameroon & 231 & & & 4.42 & 11.56 & 17.94 & & \\
\hline Kenya & 203 & 297.91 & & 0.27 & & 42.98 & 0.20 & 0.02 \\
\hline \multicolumn{9}{|c|}{ Large commercial farms } \\
\hline Burkina Faso & 495 & 12.06 & 0.54 & 1.44 & 2.08 & 27.40 & & 0.03 \\
\hline Egypt & 282 & 1248.12 & 7.41 & 1.60 & 2.66 & 6170.39 & 1.23 & 0.07 \\
\hline Ethiopia & 352 & 73.57 & 0.11 & 1.46 & 0.79 & 105.80 & & 0.11 \\
\hline Ghana & 135 & & & 0.22 & & 309.70 & & \\
\hline Niger & 142 & 56.34 & & & & & & \\
\hline Senegal & 303 & 33.67 & & 2.24 & 0.47 & 0.53 & & \\
\hline South Africa & 197 & 421.17 & 7971.38 & 470.41 & 0.46 & 5.08 & 334.15 & 6.09 \\
\hline Zambia & 103 & 3129.61 & 245.31 & 8.25 & 1.94 & 3991.26 & & \\
\hline Cameroon & 135 & & 99.30 & 29.78 & 14.11 & 859.11 & & \\
\hline Kenya & 222 & 46373.85 & 4.77 & 18.86 & & 2225.24 & 5.50 & 2.45 \\
\hline
\end{tabular}


Appendix B: Livestock and product prices

\begin{tabular}{|c|c|c|c|c|c|c|c|c|c|}
\hline \multicolumn{10}{|c|}{ Livestock prices } \\
\hline & No. & $\begin{array}{c}\text { Beef } \\
\text { cattle }\end{array}$ & $\begin{array}{l}\text { Dairy } \\
\text { cattle }\end{array}$ & Bulls & Goats & Sheep & Pigs & Oxen & Chickens \\
\hline Burkina Faso & 914 & 120 & 107 & 188 & 10 & 18 & 19 & 152 & 2 \\
\hline Egypt & 475 & 656 & 351 & 567 & 45 & 103 & & & 2 \\
\hline Ethiopia & 690 & 97 & 68 & 66 & 11 & 13 & 20 & 94 & 1 \\
\hline Ghana & 479 & 196 & 91 & 14 & 13 & 16 & 22 & 10 & 2 \\
\hline Niger & 464 & 126 & 131 & 199 & 18 & 35 & 36 & 184 & 1 \\
\hline Senegal & 795 & 138 & 169 & 241 & 20 & 43 & & 206 & 2 \\
\hline South Africa & 244 & 253 & 210 & 487 & 30 & 41 & 43 & 144 & 3 \\
\hline Zambia & 646 & 180 & 191 & 268 & 9 & 12 & 14 & 148 & 2 \\
\hline Cameroon & 366 & 168 & & & 41 & 43 & 82 & 170 & 4 \\
\hline Kenya & 425 & 165 & 151 & 207 & 20 & 20 & 41 & 146 & 2 \\
\hline \multicolumn{10}{|c|}{ Livestock product prices } \\
\hline & No. & Milk (kg) & Beef (kg) & Sheep (kg & g) Goa & s (kg) & Eggs & Wool & Leather \\
\hline Burkina Faso & 914 & 0.28 & 1.03 & 2.22 & & 15 & 0.10 & & 0.87 \\
\hline Egypt & 475 & 0.28 & 2.96 & 3.80 & & 47 & 0.05 & 1.49 & 1.63 \\
\hline Ethiopia & 690 & 0.88 & 1.44 & 1.10 & & 37 & 0.05 & 4.43 & 2.65 \\
\hline Ghana & 479 & 0.47 & & 1.18 & & 18 & 0.09 & & \\
\hline Niger & 464 & 0.28 & 1.50 & 2.19 & & 98 & 0.04 & & 1.82 \\
\hline Senegal & 795 & 0.18 & 1.92 & 2.29 & & 98 & 0.08 & & 0.69 \\
\hline South Africa & 244 & 0.28 & 1.14 & 1.68 & & 01 & 0.06 & 2.51 & 2.01 \\
\hline Zambia & 646 & 0.29 & 1.26 & 1.49 & & 25 & 0.06 & & \\
\hline Cameroon & 366 & 1.76 & 2.75 & 3.24 & & 41 & 0.34 & & \\
\hline Kenya & 425 & 0.26 & 1.62 & 2.06 & & 16 & 0.06 & 0.52 & 0.89 \\
\hline
\end{tabular}


Table 1: Mean number of livestock owned

\begin{tabular}{|c|c|c|c|c|c|c|c|c|c|c|}
\hline & $\begin{array}{l}\text { No. of } \\
\text { farms }\end{array}$ & $\begin{array}{c}\text { Beef } \\
\text { cattle }\end{array}$ & $\begin{array}{l}\text { Dairy } \\
\text { cattle }\end{array}$ & $\begin{array}{l}\text { Bulls } \\
\text { Sm }\end{array}$ & $\begin{array}{l}\text { Goats } \\
\text { all farr }\end{array}$ & Sheep & Pigs & Oxen & Chicken & $\begin{array}{c}\text { Market } \\
\text { value } \\
\text { US\$/farm }\end{array}$ \\
\hline Burkina Faso & 419 & 0.01 & 0.07 & 0.00 & 4.44 & 2.30 & 0.62 & 0.32 & 15.1 & 281 \\
\hline Egypt & 193 & 0.12 & 1.07 & 0.08 & 0.53 & 0.39 & & & 24.6 & 311 \\
\hline Ethiopia & 338 & 0.05 & 0.76 & 0.02 & 1.25 & 0.96 & 0.01 & 0.98 & 3.2 & 349 \\
\hline Ghana & 344 & 0.04 & & & 3.40 & 2.24 & 0.58 & & 13.3 & 202 \\
\hline Niger & 322 & 0.06 & 0.16 & 0.01 & 2.43 & 1.73 & 0.03 & 0.37 & 2.4 & 208 \\
\hline Senegal & 493 & & 0.00 & 0.02 & 3.76 & 2.93 & 0.03 & 0.19 & 4.5 & 221 \\
\hline S Africa & 48 & 0.19 & 0.06 & & 1.92 & 0.38 & 1.21 & & 34.8 & 216 \\
\hline Zambia & 544 & 0.04 & & 0.00 & 1.25 & 0.08 & 0.21 & 0.16 & 11.7 & 92 \\
\hline Cameroon & 232 & & & & 3.31 & 1.61 & 2.59 & & 13.2 & 239 \\
\hline Kenya & 203 & 0.07 & 1.20 & 0.01 & 1.46 & 0.57 & 0.01 & 0.14 & 10.5 & 315 \\
\hline \multicolumn{11}{|c|}{ Large farms } \\
\hline Burkina Faso & 495 & 0.69 & 2.97 & 0.85 & 11.09 & 9.47 & 2.15 & 4.57 & 23.5 & 2671 \\
\hline Egypt & 281 & 1.94 & 3.17 & 2.20 & 2.93 & 2.43 & & 0.27 & 2606.3 & 7172 \\
\hline Ethiopia & 352 & 0.46 & 4.72 & 1.81 & 7.31 & 5.27 & 0.01 & 2.19 & 5.2 & 2018 \\
\hline Ghana & 135 & 9.30 & 0.31 & 0.59 & 9.14 & 14.83 & 2.44 & 0.11 & 60.1 & 3072 \\
\hline Niger & 141 & 0.74 & 4.85 & 0.79 & 9.64 & 6.22 & 0.06 & 3.61 & 5.0 & 2123 \\
\hline Senegal & 301 & 0.22 & 3.93 & 1.88 & 14.31 & 14.93 & 0.08 & 9.15 & 7.8 & 3326 \\
\hline S Africa & 195 & 120.25 & 8.09 & 1.85 & 30.96 & 308.88 & 14.42 & 0.70 & 32.4 & 38770 \\
\hline Zambia & 102 & 35.21 & 8.41 & 1.05 & 8.19 & 7.14 & 4.01 & 2.84 & 280.5 & 10630 \\
\hline Cameroon & 134 & 7.66 & & & 6.60 & 6.63 & 18.78 & 0.54 & 637.1 & 4017 \\
\hline Kenya & 213 & 16.98 & 37.76 & 0.60 & 66.06 & 49.52 & 1.10 & 1.11 & 56.3 & 15780 \\
\hline
\end{tabular}


Table 2: Gross revenue from livestock and livestock product sales (US\$/farm)

\begin{tabular}{ccccc}
\hline & \multicolumn{2}{c}{ Small farms } & \multicolumn{2}{c}{ Large farms } \\
& Livestock & $\begin{array}{c}\text { Livestock } \\
\text { products }\end{array}$ & Livestock & $\begin{array}{c}\text { Livestock } \\
\text { products }\end{array}$ \\
\hline Burkina Faso & 28 & 11 & 183 & 68 \\
Egypt & 143 & 247 & 5340 & 1001 \\
Ethiopia & 12 & 59 & 49 & 263 \\
Ghana & 30 & 1 & 347 & 34 \\
Niger & 27 & 12 & 142 & 127 \\
Senegal & 31 & 36 & 238 & 83 \\
S Africa & 95 & 40 & 14,258 & 4200 \\
Zambia & 10 & 3 & 1086 & 1951 \\
Cameroon & 173 & 95 & 1786 & 855 \\
Kenya & 32 & 179 & 2280 & 3664 \\
\hline
\end{tabular}


Table 3: Regression of livestock net revenue (US\$/farm)

\begin{tabular}{lcc}
\hline Variable & Estimate & T-stat \\
\hline Intercept & 1042.73 & 0.17 \\
Annual mean temperature small farms* & 34.53 & 0.06 \\
Annual mean temperature sq small farms* & 1.66 & 0.14 \\
Annual mean precipitation small farms* & -56.57 & -2.58 \\
Annual mean precipitation sq small farms* & 0.23 & 2.03 \\
Annual mean temperature large farms* & -1521.91 & -3.00 \\
Annual mean temperature sq large farms* & 24.80 & 2.25 \\
Annual mean precipitation large farms* & -84.95 & -3.83 \\
Annual mean precipitation sq large farms* & 0.21 & 1.63 \\
Large farm dummy & 27284.00 & 3.37 \\
Log household size & -1023.88 & -3.31 \\
Electricity dummy & 2252.05 & 5.09 \\
Dairy farming dummy & -997.67 & -2.29 \\
Population density & 84.25 & 2.91 \\
Population density sq & -1.22 & -3.84 \\
\% Muslim & -2854.52 & -3.04 \\
\% pasture & 8433.43 & 6.00 \\
& & Adj R-sq=0.09 \\
\hline
\end{tabular}

* Climate variable multiplied by farm size dummy. Interaction terms measure farm size specific climate impacts. 
Table 4: Two-equation regression of the value of African livestock owned and the net revenue per livestock owned

\begin{tabular}{|c|c|c|c|c|}
\hline \multirow[b]{2}{*}{ Variable } & \multicolumn{2}{|c|}{$\begin{array}{l}\text { Value of } \\
\text { livestock owned }\end{array}$} & \multicolumn{2}{|c|}{$\begin{array}{l}\text { Net revenue per } \\
\text { livestock value in } \\
\text { US } 1000 \$\end{array}$} \\
\hline & Estimate & T-stat & Estimate & T-stat \\
\hline Intercept & -1288 & -0.13 & 1749 & 5.52 \\
\hline Annual mean temperature small farms* & 312 & 0.34 & -66 & -2.28 \\
\hline Annual mean temperature sq small farms* & -1.58 & -0.08 & 1 & 1.70 \\
\hline Annual mean precipitation small farms* & -118 & -3.38 & -11 & -9.75 \\
\hline Annual mean precipitation sq small farms* & 0.51 & 2.86 & 0 & 9.17 \\
\hline Annual mean temperature large farms* & -1037 & -1.29 & -54 & -2.09 \\
\hline Annual mean temperature sq large farms* & 13.15 & 0.75 & 1 & 0.97 \\
\hline Annual mean precipitation large farms* & -95.7 & -2.71 & -14 & -12.45 \\
\hline Annual mean precipitation sq large farms* & 0.07 & 0.34 & 0 & 9.56 \\
\hline Large farm dummy & 29397 & 2.28 & 79 & 0.19 \\
\hline Log household size & -2255 & -4.58 & 18 & 1.13 \\
\hline Electricity dummy & 4634 & 6.59 & 242 & 10.84 \\
\hline Dairy farming dummy & -1687 & -2.44 & 138 & 6.29 \\
\hline Population density & 134 & 2.91 & 14 & 9.82 \\
\hline Population density sq & -2.19 & -4.33 & 0 & -10.14 \\
\hline$\%$ Muslim & -4572 & -3.06 & -330 & -6.95 \\
\hline \multirow[t]{3}{*}{$\%$ pasture } & 21811 & 9.76 & -847 & -11.92 \\
\hline & & & \multicolumn{2}{|c|}{ Adj rsq $=0.21$} \\
\hline & & & & $\mathrm{N}=5062$ \\
\hline
\end{tabular}

Note: Two regressions estimated using SUR. Correlation between errors was .02.

* Climate variable multiplied by farm size dummy. Interaction terms measure farm size specific climate impacts. 
Table 5: Marginal climate effects and elasticities

\begin{tabular}{|c|c|c|c|c|c|}
\hline Types & $\begin{array}{c}\text { Current } \\
\text { livestock } \\
\text { income } \\
(\$ / \text { farm) }\end{array}$ & $\begin{array}{c}\text { Marginal } \\
\text { temperature } \\
\text { impact }\left(\$ / C^{\circ}\right)\end{array}$ & $\begin{array}{c}\text { Marginal } \\
\text { precipitation } \\
\text { impact } \\
(\$ / \mathbf{m m})\end{array}$ & $\begin{array}{c}\text { Temperature } \\
\text { elasticity }\end{array}$ & $\begin{array}{c}\text { Precipitation } \\
\text { elasticity }\end{array}$ \\
\hline \multicolumn{6}{|c|}{ Net revenue per farm } \\
\hline Small & 104.60 & 111.32 & $-26.05^{*}$ & 24.60 & $-16.63^{*}$ \\
\hline Large & 3291.03 & $-397.09 *$ & $-59.98 *$ & $-2.74^{*}$ & $-1.11 *$ \\
\hline \multicolumn{6}{|c|}{ Value of livestock owned } \\
\hline Small & 259.24 & 238.55 & $-49.20 *$ & 21.27 & $-12.68 *$ \\
\hline$\underline{\text { Large }}$ & 7794.62 & $-441.28^{*}$ & $-87.46^{*}$ & $-1.28^{*}$ & $-0.68^{*}$ \\
\hline \multicolumn{6}{|c|}{ Net revenue per livestock value } \\
\hline Small & 0.37 & $-0.02 *$ & $0.00 *$ & $-1.06^{*}$ & $-0.69 *$ \\
\hline Large & 0.39 & $-0.03 *$ & $-0.01 *$ & $-1.68^{*}$ & $-1.03 *$ \\
\hline
\end{tabular}

* significant at $5 \%$ level 
Table 6: Climate change impacts from uniform climate scenarios

\section{a) Small farm}

\begin{tabular}{lccc}
\hline & $\begin{array}{c}\text { \% impact on net } \\
\text { revenue per farm }\end{array}$ & $\begin{array}{c}\text { \% impact on value } \\
\text { of stock per farm }\end{array}$ & $\begin{array}{c}\text { impact } \\
\text { revenue/ } \\
\text { Stock value }\end{array}$ \\
\hline Baseline & 623 & 1391 & 0.37 \\
Increase temperature $2.5^{\circ} \mathrm{C}$ & $+25 \%$ & $+23 \%$ & $-10 \%$ \\
Increase temperature $5.0^{\circ} \mathrm{C}$ & $+58 \%$ & $+48 \%$ & $-15 \%$ \\
Reduce precipitation $7 \%$ & $+7 \%$ & $+5 \%$ & $2 \%$ \\
Increase precipitation $7 \%$ & $-5 \%$ & $-4 \%$ & $-1 \%$ \\
Increase precipitation $14 \%$ & $-10 \%$ & $-7 \%$ & $-3 \%$ \\
\hline
\end{tabular}

b) Large farm

\begin{tabular}{lccc}
\hline Variable & $\begin{array}{c}\text { \% impact on net } \\
\text { revenue per farm }\end{array}$ & $\begin{array}{c}\text { \% impact on value } \\
\text { of stock per farm }\end{array}$ & $\begin{array}{c}\text { impact on net } \\
\text { revenue/ } \\
\text { Stock value }\end{array}$ \\
\hline Baseline & 3142 & 6596 & 0.40 \\
Increase temperature $2.5^{\circ} \mathrm{C}$ & $-22 \%$ & $-14 \%$ & $-17 \%$ \\
Increase temperature $5.0^{\circ} \mathrm{C}$ & $-35 \%$ & $-25 \%$ & $-32 \%$ \\
Reduce precipitation $7 \%$ & $+5 \%$ & $+5 \%$ & $4 \%$ \\
Increase precipitation $7 \%$ & $-5 \%$ & $-5 \%$ & $-3 \%$ \\
Increase precipitation $14 \%$ & $-9 \%$ & $-9 \%$ & $-7 \%$ \\
\hline
\end{tabular}


Table 7: AOGCM climate scenarios

\begin{tabular}{ccccc}
\hline & Current & $\mathbf{2 0 2 0}$ & $\mathbf{2 0 6 0}$ & $\mathbf{2 1 0 0}$ \\
\hline Temperature $\left(\mathbf{C}^{\circ}\right)$ & & & & \\
CCC & 23.29 & 24.94 & 26.85 & 29.96 \\
CCSR & 23.29 & 25.27 & 26.17 & 27.39 \\
PCM & 23.29 & 23.95 & 24.94 & 25.79 \\
\hline Rainfall (mm/mo) & & & & \\
CCC & 79.75 & 76.84 & 71.86 & 65.08 \\
CCSR & 79.75 & 73.99 & 76.67 & 62.44 \\
PCM & 79.75 & 89.58 & 80.72 & 83.18 \\
\hline
\end{tabular}


Table 8: Change in net revenue for each AOGCM climate prediction (US\$/farm)

\begin{tabular}{|c|c|c|c|c|}
\hline Variable & $\begin{array}{c}\text { Impact per } \\
\text { small farm } \\
\text { (\$/farm) }\end{array}$ & $\begin{array}{c}\text { \% of livestock } \\
\text { income }\end{array}$ & $\begin{array}{c}\text { Impact per } \\
\text { large farm } \\
\text { (\$/farm) }\end{array}$ & $\begin{array}{c}\text { \% of livestock } \\
\text { income }\end{array}$ \\
\hline \multicolumn{5}{|l|}{2020} \\
\hline Change_CCC & 151 & $24 \%$ & -290 & $-9 \%$ \\
\hline Change_CCSR & 259 & $42 \%$ & -317 & $-10 \%$ \\
\hline Change_PCM & -26 & $-4 \%$ & -545 & $-17 \%$ \\
\hline \multicolumn{5}{|l|}{2060} \\
\hline Change_CCC & 332 & $53 \%$ & -639 & $-20 \%$ \\
\hline Change_CCSR & 180 & $29 \%$ & -750 & $-24 \%$ \\
\hline Change_PCM & 40 & $6 \%$ & -709 & $-23 \%$ \\
\hline \multicolumn{5}{|l|}{2100} \\
\hline Change_CCC & 720 & $116 \%$ & -722 & $-23 \%$ \\
\hline Change_CCSR & 945 & $152 \%$ & 2 & $0 \%$ \\
\hline Change_PCM & 194 & $31 \%$ & -842 & $-27 \%$ \\
\hline
\end{tabular}

Note: Small farms have a baseline income of $\$ 623$ per farm.

Large farms have a baseline income of $\$ 3142$ per farm. 
Table 9: Change in value of livestock owned for each AOGCM climate prediction (US\$/farm)

\begin{tabular}{lcccc}
\hline \multicolumn{1}{c}{ Variable } & $\begin{array}{c}\text { Impact per } \\
\text { small farm } \\
\mathbf{( \$ / f a r m )}\end{array}$ & $\begin{array}{c}\text { \% of livestock } \\
\text { income }\end{array}$ & $\begin{array}{c}\text { Impact per } \\
\text { large farm } \\
\mathbf{( \$ / f a r m )}\end{array}$ & $\begin{array}{c}\text { \% of livestock } \\
\text { income }\end{array}$ \\
\hline 2020 & & & & \\
Change_CCC & 297 & $21 \%$ & -405 & $-29 \%$ \\
Change_CCSR & 504 & $36 \%$ & -387 & $-28 \%$ \\
Change_PCM & -24 & $-2 \%$ & -888 & $-64 \%$ \\
\hline 2060 & & & & $-68 \%$ \\
Change_CCC & 628 & $45 \%$ & -944 & $-86 \%$ \\
Change_CCSR & 378 & $27 \%$ & -1192 & $-75 \%$ \\
Change_PCM & 96 & $7 \%$ & -1037 & $-92 \%$ \\
\hline \multicolumn{1}{c}{ 2100 } & & & & $-4 \%$ \\
Change_CCC & 1263 & $91 \%$ & -1276 & $-104 \%$ \\
Change_CCSR & 1904 & $137 \%$ & -1442 & \\
Change_PCM & 446 & $32 \%$ & & \\
\hline
\end{tabular}

Note: Small farms have a baseline value of livestock of $\$ 1392$ per farm.

Large farms have a baseline value of livestock of $\$ 6596$ per farm. 
Table 10: Change in net revenue per value of livestock owned for each AOGCM climate prediction

\begin{tabular}{|c|c|c|c|c|}
\hline Variable & $\begin{array}{c}\text { Small farm net } \\
\text { revenue per } \\
\text { value of animal } \\
(\$ / \$)\end{array}$ & $\begin{array}{l}\text { \% of net } \\
\text { revenue per } \\
\text { animal }\end{array}$ & $\begin{array}{c}\text { Large farm net } \\
\text { revenue per } \\
\text { value of animal } \\
(\$ / \$)\end{array}$ & $\begin{array}{l}\text { \% of net } \\
\text { revenue per } \\
\text { animal }\end{array}$ \\
\hline \multicolumn{5}{|l|}{2020} \\
\hline Change_CCC & -0.02 & $-5 \%$ & -0.03 & $-7 \%$ \\
\hline Change_CCSR & 0.00 & $-1 \%$ & -0.03 & $-7 \%$ \\
\hline Change_PCM & -0.02 & $-5 \%$ & -0.04 & $-11 \%$ \\
\hline \multicolumn{5}{|l|}{2060} \\
\hline Change_CCC & -0.02 & $-6 \%$ & -0.06 & $-15 \%$ \\
\hline Change_CCSR & -0.04 & $-11 \%$ & -0.08 & $-21 \%$ \\
\hline Change_PCM & -0.02 & $-6 \%$ & -0.05 & $-13 \%$ \\
\hline \multicolumn{5}{|l|}{2100} \\
\hline Change_CCC & -0.03 & $-7 \%$ & -0.09 & $-23 \%$ \\
\hline Change_CCSR & 0.09 & $24 \%$ & 0.07 & $17 \%$ \\
\hline Change_PCM & -0.02 & $-4 \%$ & -0.07 & $-17 \%$ \\
\hline
\end{tabular}

Note: Small farms have a baseline net revenue per dollar of animal owned of $\$ 0.38$ per farm. Large farms have a baseline net revenue per dollar of animal owned of $\$ 0.40$ per farm. 
Table 11: Aggregate change in livestock net revenue in Africa caused by each AOGCM scenario (billions US\$/year)

\begin{tabular}{cccc}
\hline Variable & $\begin{array}{c}\text { Total impact to } \\
\text { small farms }\end{array}$ & $\begin{array}{c}\text { Total impact to } \\
\text { large farms }\end{array}$ & $\begin{array}{c}\text { Total impact to } \\
\text { all farms }\end{array}$ \\
\hline 2020 & & & \\
Change_CCC & +1.26 & -5.63 & -4.37 \\
Change_CCSR & +2.13 & -6.15 & -4.02 \\
Change_PCM & -0.22 & -10.57 & -10.79 \\
\hline \multicolumn{1}{c}{ 2060 } & & & -9.63 \\
Change_CCC & +2.77 & -12.40 & -13.05 \\
Change_CCSR & +1.50 & -14.55 & -13.42 \\
Change_PCM & +0.33 & -13.75 & \\
\hline \multicolumn{1}{c}{ 2100 } & & & -8.01 \\
Change_CCC & +6.00 & -14.01 & +7.92 \\
Change_CCSR & +7.88 & +0.04 & -14.72 \\
Change_PCM & +1.61 & -16.33 & \\
\hline
\end{tabular}




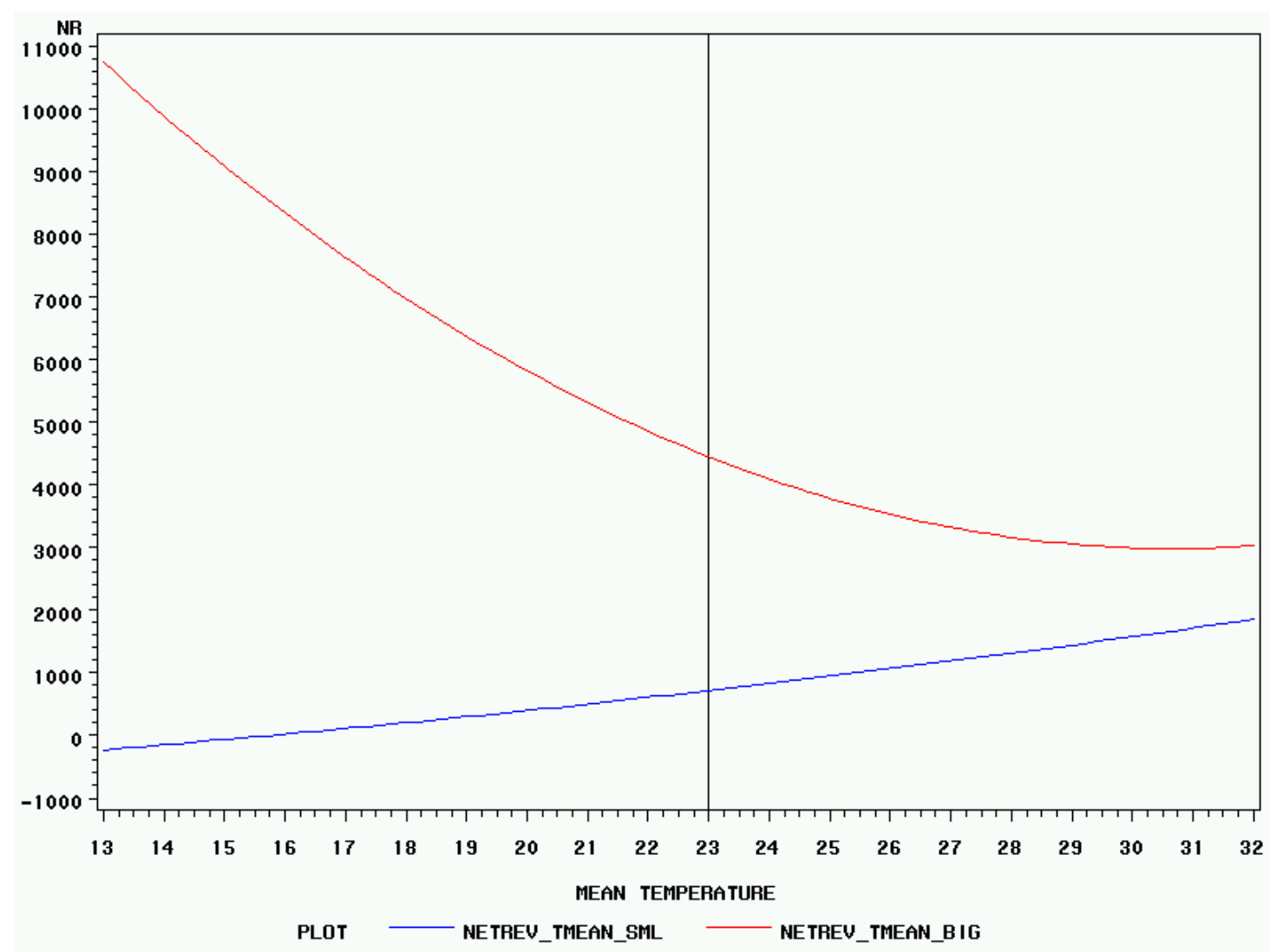

Figure 1: Net revenue per farm temperature response functions 


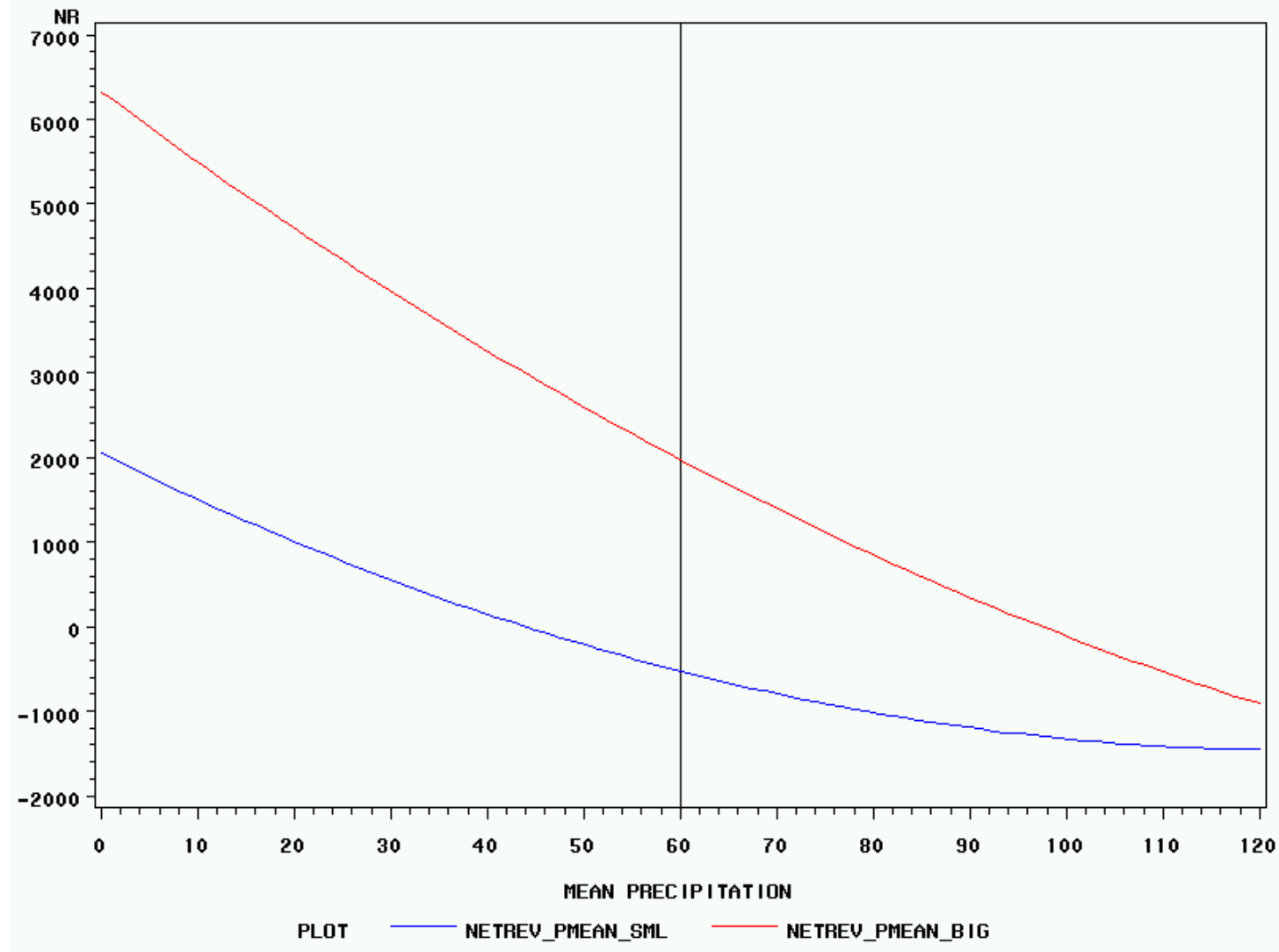

Figure 2: Net revenue per farm precipitation response functions 


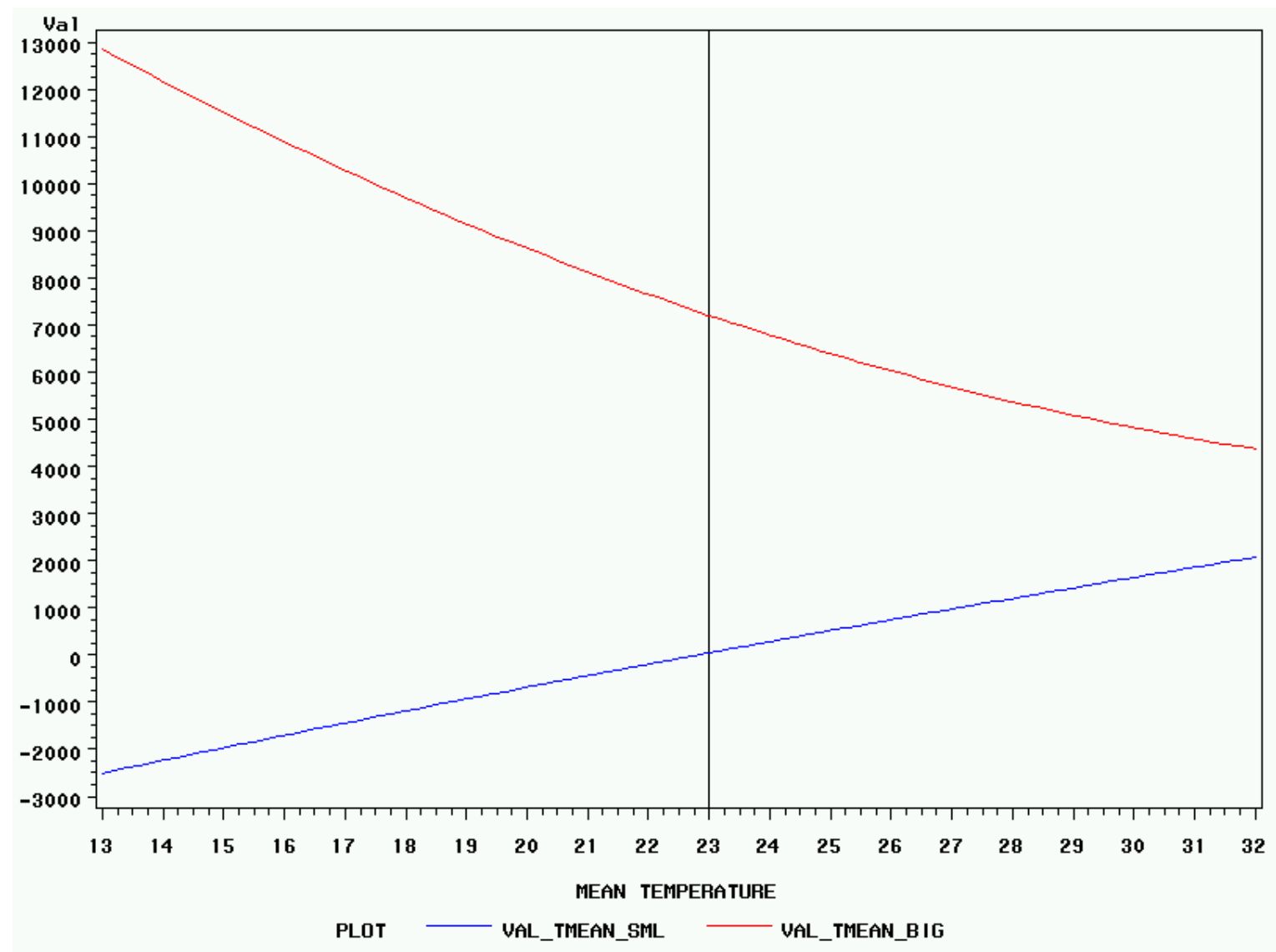

Figure 3: Livestock value temperature response functions 


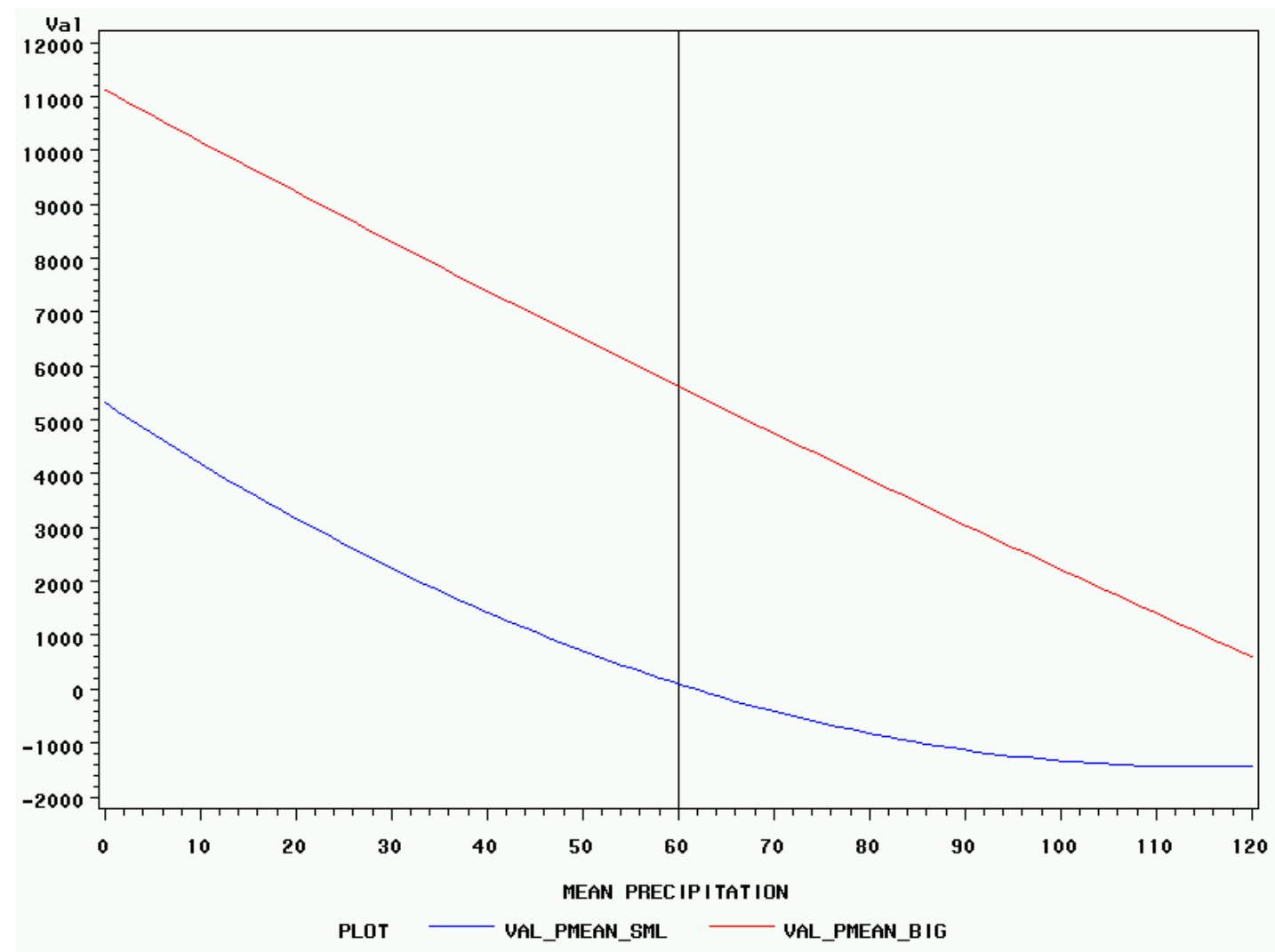

Figure 4: Livestock value precipitation response functions 


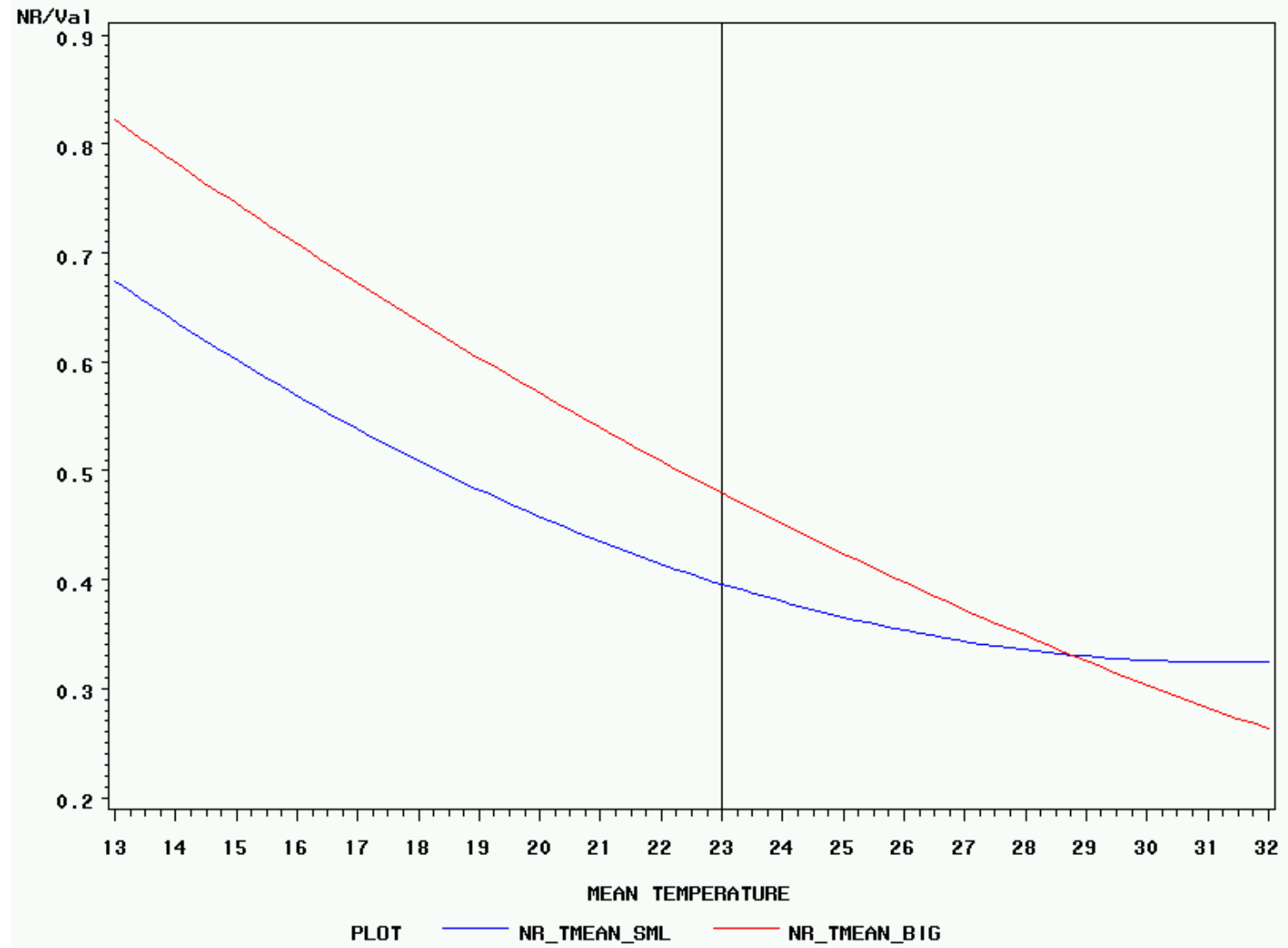

Figure 5: Net revenue per livestock value temperature response functions 


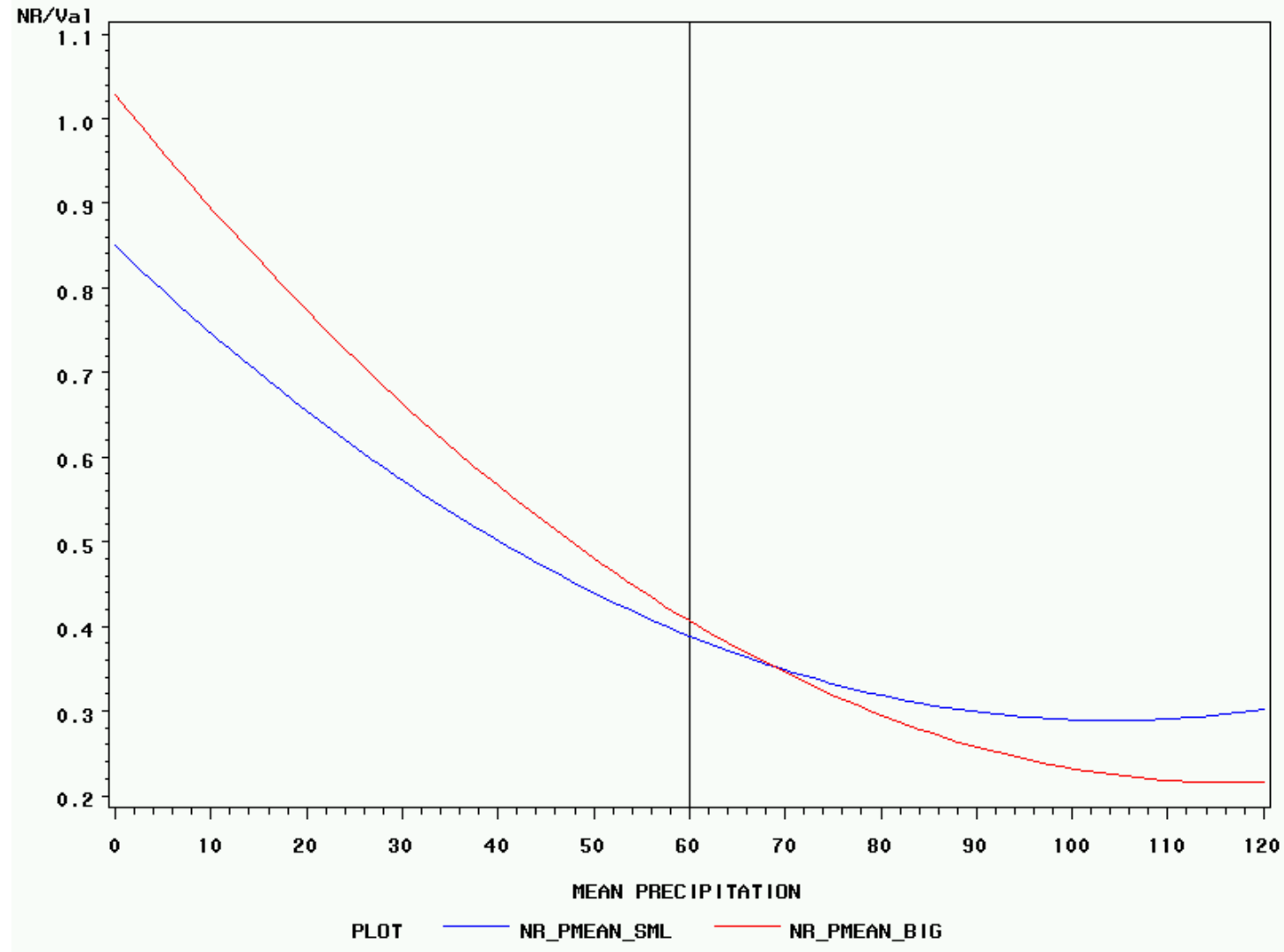

Figure 6: Net revenue per livestock value precipitation response functions 


\section{2100, Small Farms}
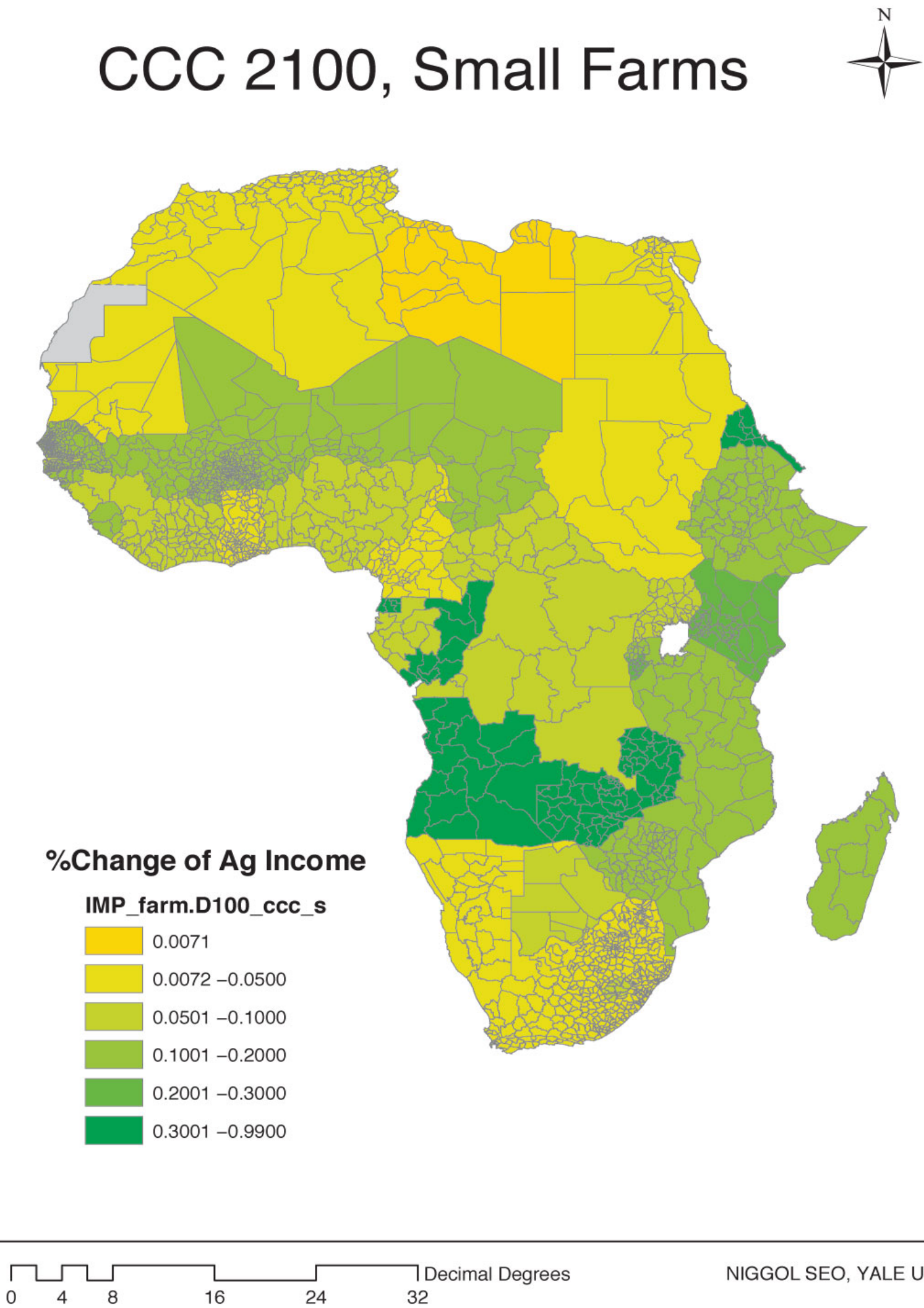

NIGGOL SEO, YALE UNIV.

Figure 7: Map of impacts in 2100 for small farms based on CCC scenario 


\section{CCSR 2100, Small Farms}
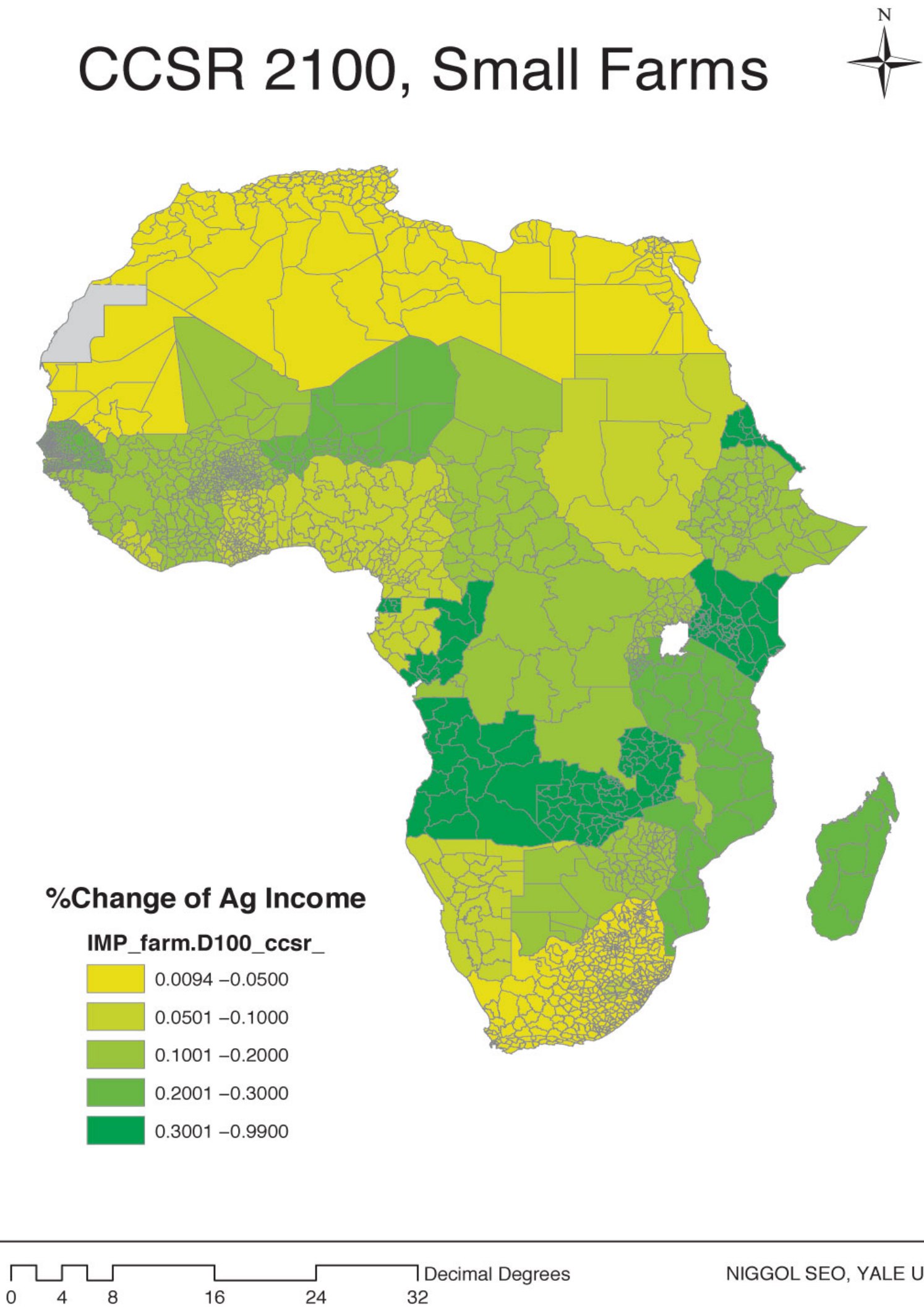

NIGGOL SEO, YALE UNIV.

Figure 8: Map of impacts in 2100 for small farms based on CCSR scenario 


\section{PCM 2100, Small Farms}
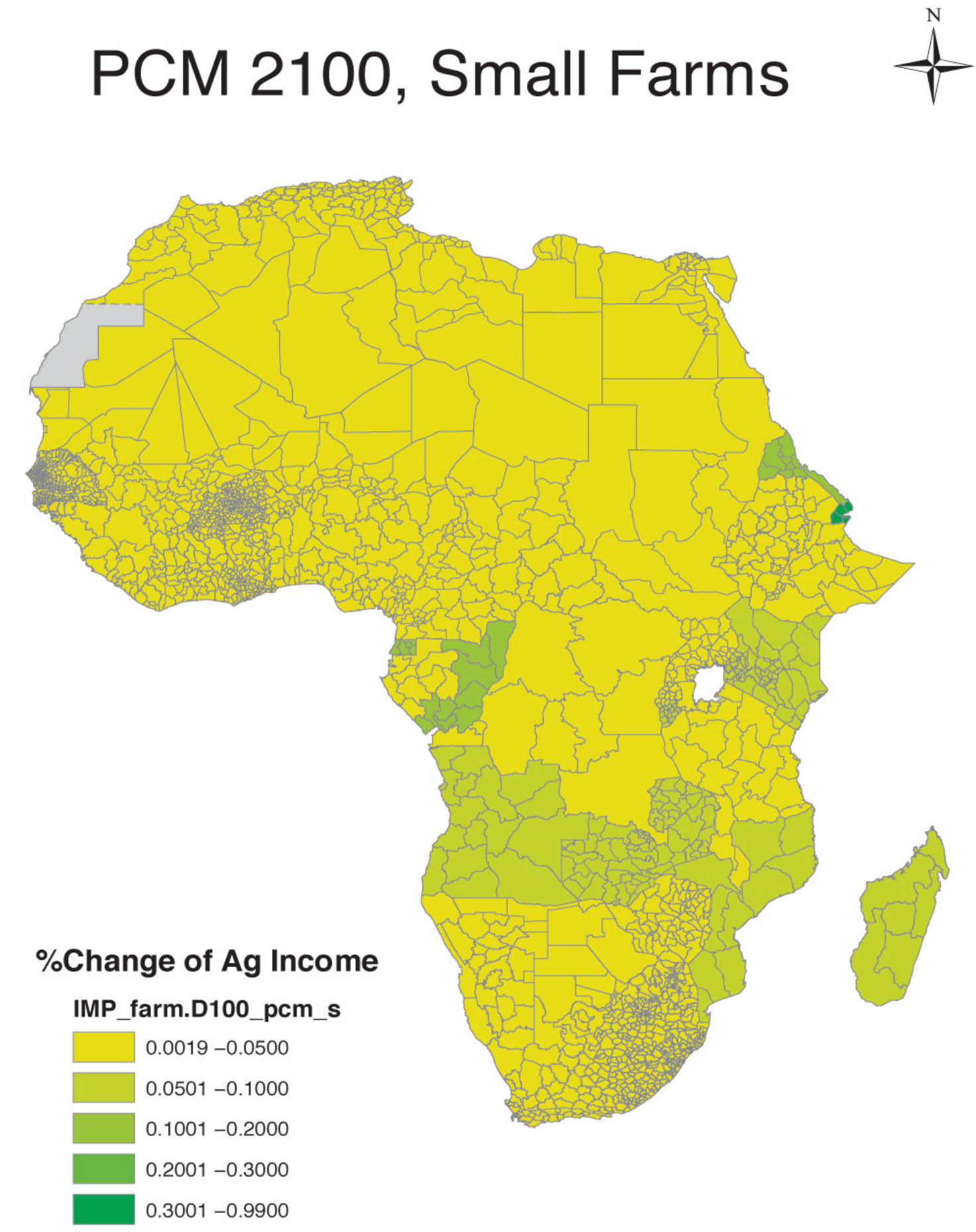

NIGGOL SEO, YALE UNIV.

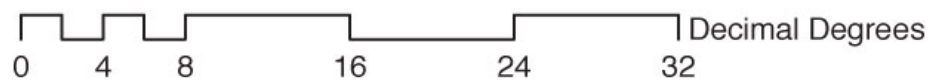

Figure 9: Map of impacts in 2100 for small farms based on PCM scenario 


\section{2100, Large Farms}
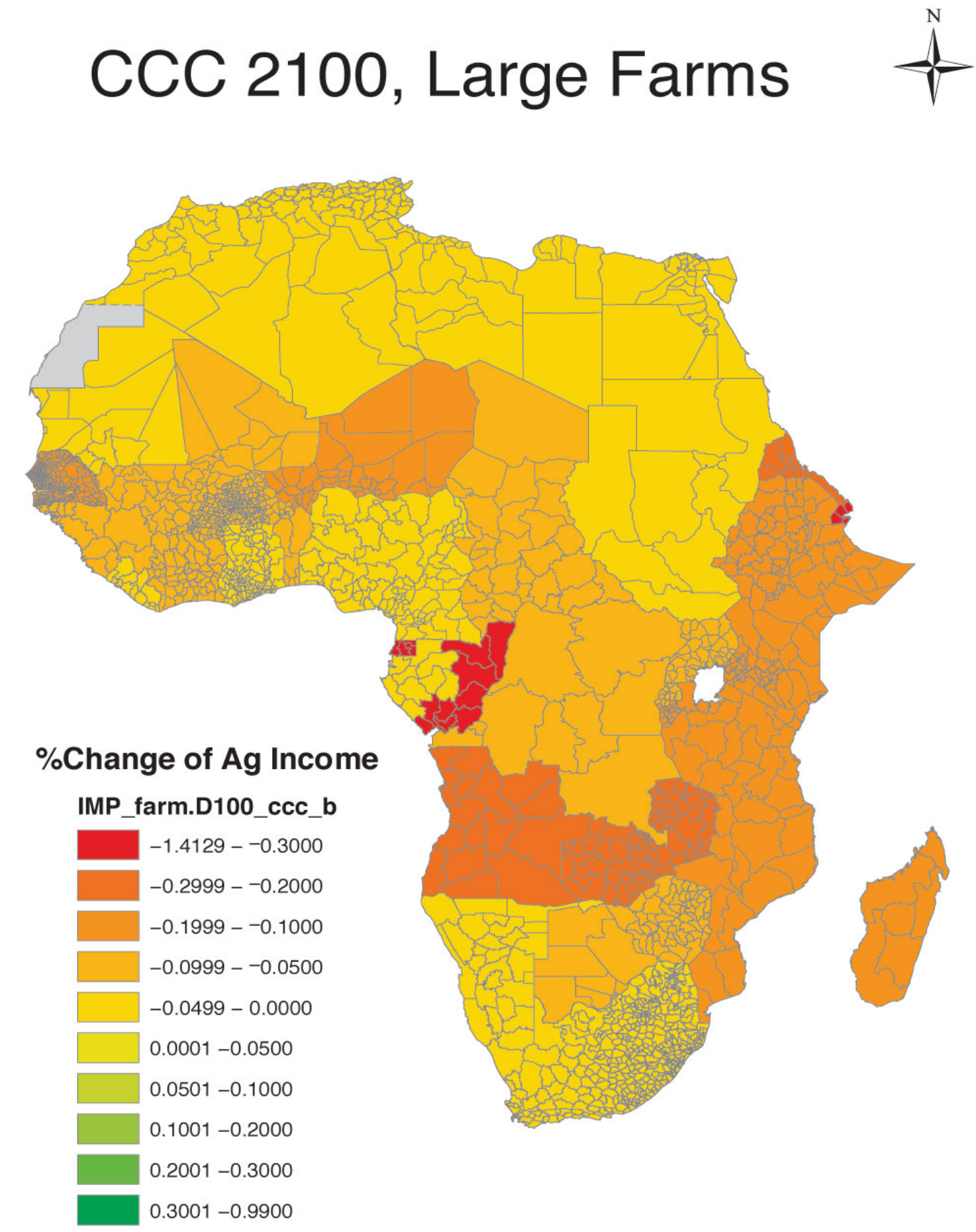

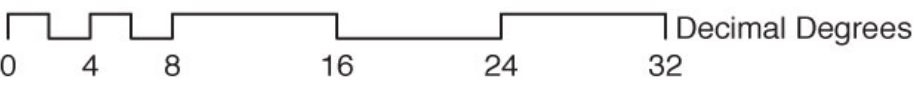

NIGGOL SEO, YALE UNIV.

Figure 10: Map of impacts in 2100 for large farms based on CCC scenario 


\section{CCSR 2100, Large Farms

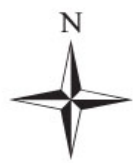

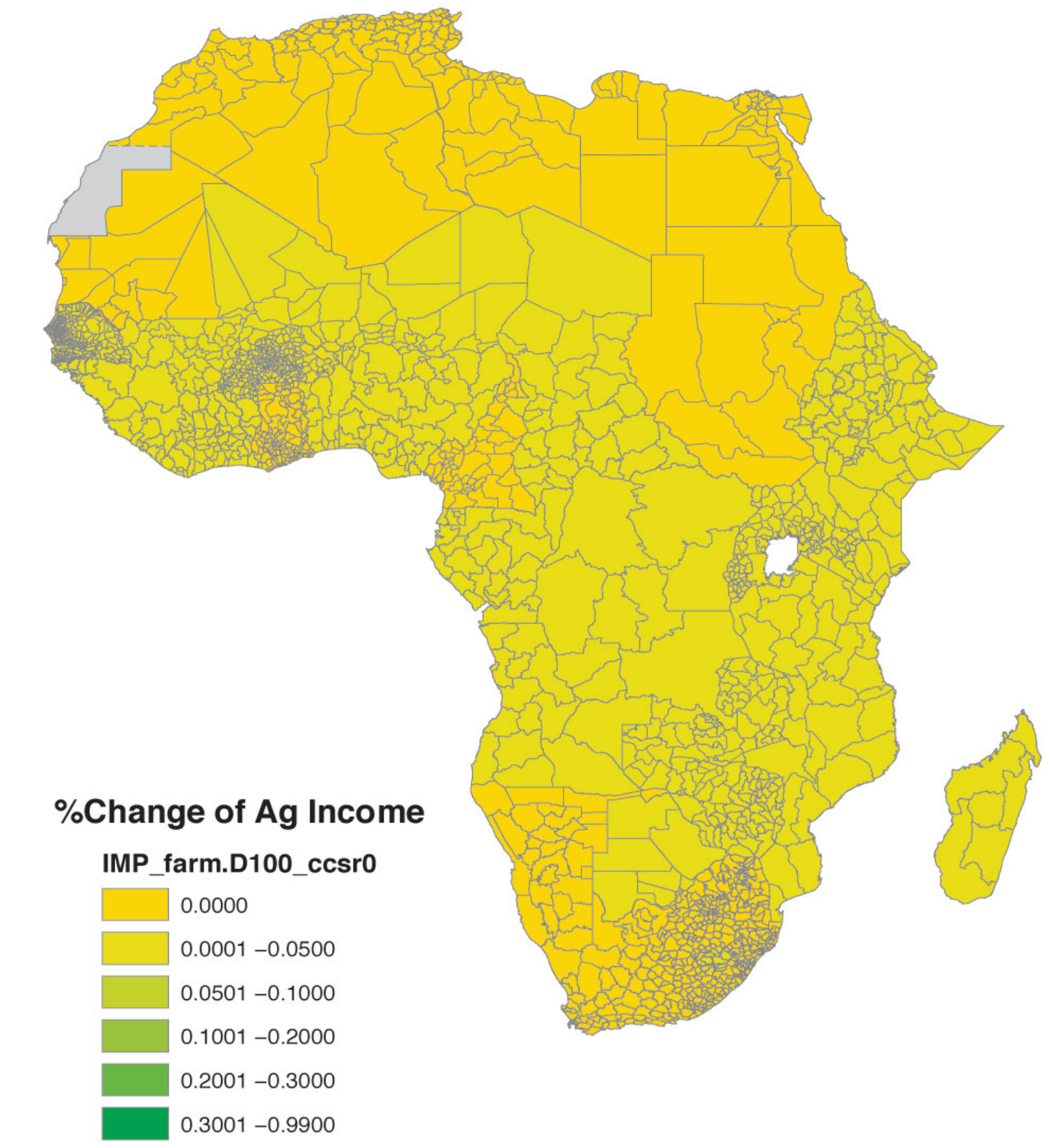

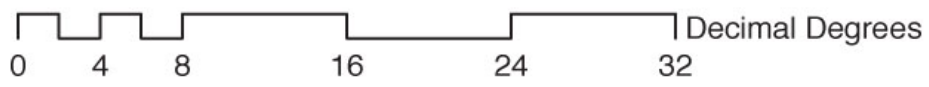

NIGGOL SEO, YALE UNIV.

Figure 11: Map of impacts in 2100 for large farms based on CCSR scenario 


\section{PCM 2100, Large Farms}
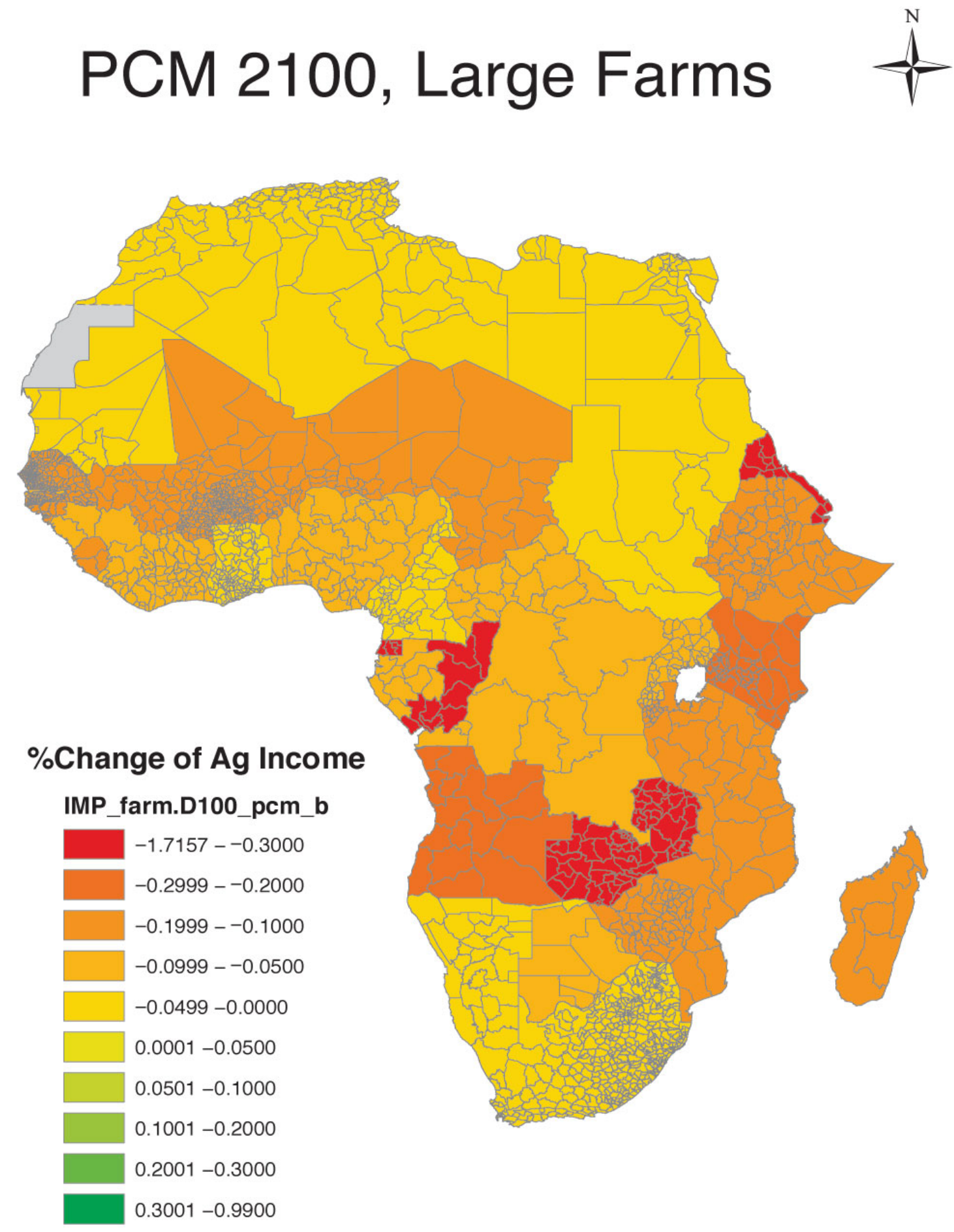

NIGGOL SEO, YALE UNIV. 32

Figure 12: Map of impacts in 2100 for large farms based on PCM scenario 